\title{
Monetary Policy and Inflation Performance: Evidence from Exchange Rate Regimes in Sri Lanka
}

\author{
P.K.G. Harischandra*
}

\begin{abstract}
This paper examines empirical evidence on monetary policy and inflation performance across exchange rate regimes in Sri Lanka. The criterion used to examine inflation performance is the degree of inflation persistence. Three alternative definitions of inflation persistence are used to model inflation dynamics. First, autocorrelation properties of inflation process are examined. Estimates of traditional Phillips curve and the hybrid-new Keynesian Phillips curve (H-NKPC) suggest a significant upward shift in inflation persistence following the change in exchange rate system in late 1977. Recursive estimates of coefficient on lagged inflation and Chow parameter stability tests confirm these results. Second, inflation response to systematic monetary policy actions is examined. Results suggest that inflation is more persistent and monetary policy is more accommodative in the flexible exchange rate regime. However, the correlation between money growth and inflation is found to be modest. Finally, inflation response to non-systemic policy actions (i.e., policy shocks) is examined through impulse response functions of an unrestricted VAR system. Results suggest that policy shocks are more persistent in the flexible exchange rate regime, than in the fixed exchange rate regime. However, maximum lag length of inflation response to a policy shock is not significantly different across regimes, suggesting that results from the impulse response analysis are inconclusive. Overall, there is substantial evidence to suggest that the shift in inflation persistence coincides with the change in exchange rate regimes. Moreover, during the flexible regime, higher monetary accommodation has resulted in higher inflation persistence. Because of sluggish response of inflation to changes in monetary policy measures, more stringent monetary policy measures may be needed to curb inflationary pressures.
\end{abstract}

(JEL E 31, E 52)

Key Words: Inflation Persistence, Monetary Policy, Exchange Rate Regimes

\footnotetext{
* The author wishes to thank Dr. George Chouliarakis for his useful comments. This paper is based on the dissertation submitted in partial fulfillment of the requirements for the M.Sc. in Economics, the University of Manchester, United Kingdom.
} 


\section{Introduction}

Does the nominal exchange rate regime matter for macroeconomic performance? is widely a discussed topic in the open economy literature. One of the key aspects of this strand of research deals with the relation between exchange rate regimes and inflation performance. Thus, many studies attempt to examine the effects of exchange rate regime on the conduct of monetary policy. The underlying theme of those studies is to analyse the degree of inflation persistence across different exchange rate regimes. While some authors report a direct relation between shifts in exchange rate regimes and the degree of inflation persistence [see for example, Alogoskoufis and Smith (1991), Alogoskoufis (1992), Obstfeld, (1995)], others argue, instead, that shifts in inflation persistence may coincide with factors like oil price shocks, outbreak of wars, and economic reforms and central bank reforms etc. [Burdekin and Siklos (1999), Bleaney (2001)]. The explanation for the former argument suggests that lower degree of monetary accommodation in the fixed exchange rate regime results in lower inflation persistence, while the contrary occurs in the flexible exchange rate regime. However, in Sri Lanka, only limited attempts have, so far, been made, to examine the implications of exchange rate regimes on inflation performance. ${ }^{1}$

The key policy implication of a regime change derives from the fact that the central bank's monetary autonomy in making policy decisions may vary between regimes. Under flexible exchange rate regime central bank can adopt discretionary monetary policy, to soften the effects of price increases, which may result in more persistence. By contrast, under fixed exchange rate regimes central bank is committed to defend the exchange rate parity, which results in lower degree of monetary policy autonomy, subsequently, lowe inflation persistence through contained discretionary accommodation. However, the views among researchers on this explanation are, often, divisive. Agenor (2004) reports that "simply pegging the exchange rate did not prove to be a substitute for maintaining monetary stability and credibility. [...] Recent experiences suggest that exchange rate pegs can be sustainable only when they are credible, and credibility is to a large extent determined by domestic macroeconomic policies" (p.150). Thus, the effectiveness of a policy change may be dependent upon several factors. As Agenor and Taylor (1992) report, lack of confidence of public in the newly implemented policy may be caused by $(a)$ perceived inconsistency between other policies that are pursued by the government simultaneously, $(b)$ timeinconsistency problem faced by the government between the ex-ante and ex-post strategies, (c) incomplete or asymmetric information that may hinder private agents' ability to asses the effects of policy change, and finally, $(d)$ uncertainty about the predictability of policy reforms due to exogenous shocks that are caused by external factors. In general, private agents' expectations with regard to a policy change will greatly influence the sustainability

1/ Of course, to our knowledge, this is the first study, which examines the relation between inflation persistence and exchange rate regimes in Sri Lanka. of the new policy.

\section{A. Classification of Exchange Rate Regimes ${ }^{2}$}

Sri Lanka has experienced several exchange rate regime changes during the past five decades. Table 1.1 summarises the evolution of exchange rate regimes in Sri Lanka since 1949. However, all the regimes can broadly be categorised into three groups, namely, fixed exchange rate regime, managed float with a crawling band and an independent floating system. The fixed exchange rate regime which lasted for nearly thirty years came to a halt with the introduction of major economic liberalization policies by end of 1977. Since then, the exchange rate system has been subject to several changes within a flexible exchange rate regime framework, including a major shift towards an independent floating system, introduced in early 2001.

However, classifying exchange rate regimes has become a debatable issue, in the

Table 1.1 - Evolution of Exchange Rate Regimes in Sri Lanka

\begin{tabular}{lll}
\hline Date & Major Changes & Exchange Rate Regime \\
\hline 1949 & Rupee was linked to sterling pound & Fixed \\
22 Nov 1967 & Rupee was depreciated by 20\% & Fixed \\
06 May 1968 & $\begin{array}{l}\text { Introduced Foreign Exchange Entitlement } \\
\text { Certificate Scheme }\end{array}$ & Dual exchange rate system \\
01 Aug 1971 & Rupee was linked to US dollar & - do - \\
10 July 1972 & Rupee was linked to sterling pound & - do - \\
24 May 1976 & $\begin{array}{l}\text { Rupee was pegged to a weighed average basket } \\
\text { of currencies }\end{array}$ & - do - \\
12 March 1977 & Rupee was depreciated by 20\% & - do - \\
16 Nov 1977 & $\begin{array}{l}\text { Dual exchange rate system was abolished and } \\
\text { managed floating exchange rate system was }\end{array}$ & $\begin{array}{l}\text { Managed floating with crawling } \\
\text { band }\end{array}$ \\
20 June 2000 & introduced & $\begin{array}{l}\text { Managed floating with horizontal } \\
\text { band }\end{array}$ \\
03 Nov 2000 & Band was widened & $\begin{array}{l}\text { Managed floating with crawling } \\
\text { band }\end{array}$ \\
23 Jan 2001 & $\begin{array}{l}\text { Central Bank stopped announcing its buying and } \\
\text { selling rates in advance }\end{array}$ & Independent floating \\
\hline
\end{tabular}
Source: Central Bank of Sri Lanka - Annual Report 2001

2/ The terms 'fixed exchange rate regime' and 'flexible exchange rate regime' would, respectively, be referred to as 'fixed regime' and 'flexible regime', for brevity. 
recent literature. The official source of information on exchange rate policy is the de jure classification presented by the International Monetary Fund (IMF) for its member countries (the Annual Report on Exchange Arrangements and Exchange Restrictions). The information contained in this report has been challenged by various authors claiming that countries may not always follow the exchange rate policy as they announce [see for example, Shambaugh (2004), Reinhart and Rogoff (2004), and Levy-Yeyati and Sturzenegger (2005)]. In line with this argument, Agenor (2004) reports that "many of the countries that now claim to have independent floating rates use official intervention to alter the exchange rate path and should be classified as managed floaters or de facto peggers". (p.173). Thus, several studies attempt to provide alternative de facto classifications, based on observed behaviour of exchange rate performance. Consequently, IMF itself started publishing a de facto classification based on actual arrangements of member countries, which may differ from the de jure classification, and its publication for 2006 classifies Sri Lanka under Managed floating with no pre-determined path for the exchange rate and monetary aggregate target framework.

However, recent studies suggest that, in order to avoid misclassification problems, exchange rate regimes should be examined under broader categorisation. Therefore, this study classifies exchange rate regimes in Sri Lanka into two categories, namely, fixed regime (from 1960Q1 to 1977Q3) and flexible regime (from 1977Q4 to 2005Q4).

A brief review of inflation rates across different exchange rate regimes provides a significant piece of evidence on inflation dynamics across regimes. As Table 1.2 shows, there is a dramatic shift in mean inflation during the flexible regime, which is nearly three times higher than in the fixed regime. The volatility of inflation has also been much higher during the flexible regime, as measured by the standard deviation of 5.80. Figure 1.1 also depicts the volatility of inflation rates between regimes.

Table 1.2 - Descriptive Statistics of Consumer Price Inflation over Exchange Rate Regimes

\begin{tabular}{lccc}
\hline & $\begin{array}{c}\text { Full Sample Period } \\
\text { (1960Q1-2005Q4) }\end{array}$ & $\begin{array}{c}\text { Fixed Exchange Rate } \\
\text { Regime } \\
\text { (1960Q1-1977Q3) }\end{array}$ & $\begin{array}{c}\text { Flexible Exchange } \\
\text { Rate Regime } \\
\text { (1977Q4-2005Q4) }\end{array}$ \\
\hline Mean & 8.44 & 3.83 & 11.34 \\
Standard Deviation & 6.31 & 3.89 & 5.80 \\
Maximum & 29.93 & 14.18 & 29.93 \\
Minimum & -3.6 & -3.6 & -0.88 \\
\hline
\end{tabular}

Figure 1.1 - Consumer Price Inflation across Exchange Rate Regimes

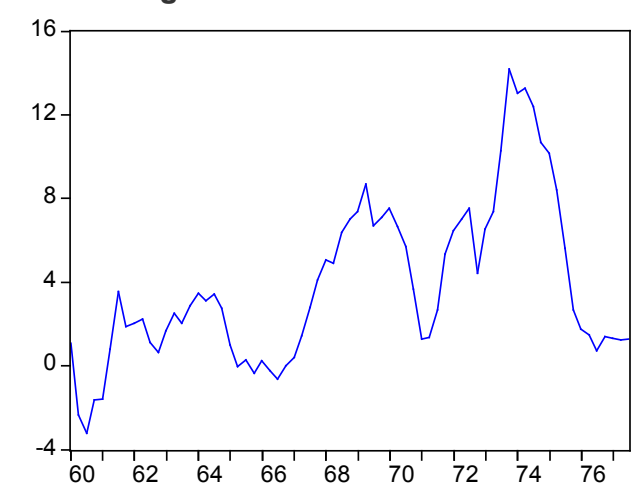

(a) Fixed Exchange Rate Regime

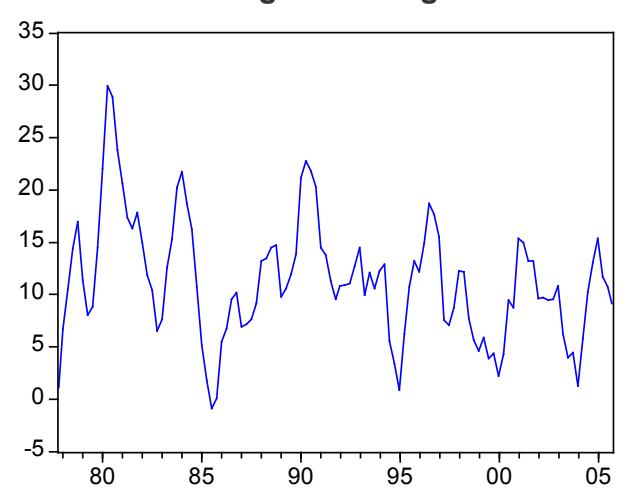

(b) Flexible Exchange Rate Regime
As claimed by various authors, modelling inflation persistence appears to have been a critical issue. One of the major concerns is attributed to the issue of how to define inflation persistence. Batini and Nelson (2001, p.383) describe three types of inflation persistence:

(I) Positive serial correlation in inflation

(II) Lags between systematic monetary policy actions and their (peak) effect on inflation

(III) Lagged response of inflation to non-systematic policy actions (i.e., policy shocks).

The type I inflation persistence relates to autocorrelation properties of inflation as discussed in various studies [see for example Fuhrer and Moore (1995), Cogley and Sargent (2001), Sbordone (2002)]. The type II relates to the number of lags between the change in monetary policy measure and maximum effect on inflation, as described by Freidman (1972). The type III inflation persistence refers to the effects of policy shocks on inflation, which is often measured by means of impulse response functions. Policy shocks can be either monetary policy shocks [as discussed by Christiano et al., (1999); (2001), McCallum (1999)] or non-policy shocks such as technology, preferences, government spending etc. (see for example Christiano et al. 2001). However, Batini (2002) reports that " $[t]$ he economic literature is not unanimous about the definition of inflation persistence" (p.10). Sheedy (2005) also shares the same view that "[t]he debate on inflation persistence has been hindered by the lack of a clear definition". He brings about the idea of structural inflation persistence which is the "inflation inherited from the past which cannot be avoided without suffering a reduction in economic activity". However, he asserts that most of studies tend to use either autocorrelation function of inflation or impulse response functions. 
Similarly, there is no consensus on the issue of theoretical modelling of inflation persistence. Recently, the use of new Keynesian Phillips curve (NKPC) to model inflation dynamics has been highlighted by many researchers. Specially, the open economy new Keynesian models highlight the relation between nominal exchange rate regime and the response of economy to monetary or real disturbances. These models predict that under fixed exchange rates, due to price stickiness, real exchange rate shows a lower degree of persistence in the short run, while the central bank defends the nominal exchange rate parity By contrast, under flexible exchange rates, nominal exchange rate is greatly influenced by expectations of future behaviour of money supply and interest rates. However, there are some disagreements among researchers on the issue of using NKPC to model inflation. Some argue that the NKPC is incapable of accounting for inflation persistence due to its purely forward looking nature. As a result, the hybrid version of the NKPC is widely used in recent literature, which includes both forward looking as well as backward looking components.

\section{B. Objectives of the Study}

As described, the purpose of this paper is to examine monetary policy and inflation performance under different exchange rate regimes in Sri Lanka. The criterion used to examine inflation performance is 'inflation persistence' across regimes. The sample period spans from 1960Q1 to 2005Q4 and, the exchange rate regimes are broadly categorized into fixed and flexible regimes. Fixed exchange rate regime comprises of pegged exchange rate arrangements and dual exchange rate regimes, while flexible exchange rate regime comprises of managed floating with crawling band, managed floating with horizontal bands and independent floating.

Accordingly, the paper is intended to,

(i) examine inflation persistence across fixed and flexible regimes in order to identify whether shifts in inflation persistence coincide with changes in exchange rate regimes,

(ii) examine inflation response to changes in (systematic) monetary policy measures and the degree of monetary accommodation under fixed and flexible regimes and;

(iii) identify inflation response to monetary policy shocks (i.e., non-systematic policy actions) under fixed and flexible regimes.

The structure of the paper is as follows. Section 2 reviews existing literature on both empirical and theoretical grounds on the issue. Section 3 describes the theoretical model and the methodology adopted in this paper. Section 4 presents the findings and analysis. Section 5 concludes.

\section{Literature Review}

Recently, a large volume of research is devoted to study inflation dynamics. Various theoretical and empirical models explain behaviour of macroeconomic variables under different monetary and exchange rate regimes. However, it is noted that most of early work examining inflation persistence is based on traditional Phillips curve literature, while the models developed more recently are based on the new Keynesian framework. This section briefly describes empirical and theoretical underpinnings on the issue.

The empirical evidence on inflation persistence over exchange rate regimes draw mixed conclusions. Some argue that shifts in inflation persistence are associated with changes in monetary and exchange rate regimes, while some find no direct relation between the two, and suggest that shits in inflation persistence could occur due to various other factors like wars, oil price shocks and institutional reforms etc. Early contributions on the empirical analysis of inflation persistence and exchange rate regimes are due to Alogoskoufis and Smith, (1991, henceforth, AS), Alogoskoufis, (1992), and Obstfeld (1995). Subsequently, several studies attempt to test empirical validity of AS's findings with wider country coverage and extended data sample. However, contrasting views emerge among researchers with regard to AS's initial findings [Burdekin and Siklos (1999), Bleaney (2001).

\section{A. Inflation Persistence and Traditional Phillips Curve}

Alogoskoufis and Smith, (1991) provide a good starting point for the discussion of the behaviour of monetary variables under different exchange rate regimes. They examine shifts in inflation persistence using the price inflation process and expectation-augmented Phillips curve for U.K. and U.S. data, under broader regime categorization i.e., fixed and managed floating exchange rate regimes. They conclude that the fixed exchange rate regime is associated with lower monetary accommodation while the managed float shows a higher monetary accommodation. Similarly, estimates of inflation persistence coefficients suggest that during the fixed regime, inflation persistence has been low due to less monetary accommodation, where as in the managed float, inflation is highly persistent due to higher accommodation. Further, Alogoskoufis (1992) extends the same analysis for OECD countries using annual data from 1952 to 1987 and re-confirm the findings.

Subsequently, Obstfeld (1995) examines inflation persistence in twelve industrialised countries based on annual data during the post-war period. Results are in consistent with AS's findings. He shows that under floating regime, monetary authorities accommodate inflation more than under fixed regime, which results in greater inflation persistence. However recently, Burdekin and Siklos (1999) and Bleaney (2001) provide contrasting evidence to theses findings. Burdekin and Siklos (1999) show that inflation persistence has changed over time for reasons which are not solely attributed to shifts in exchange rate regimes. They extend AS's Phillips curve analysis by including data for Canada and Sweden with the 
updated data for U.K. and U.S. Their findings are partly contradictory to the conclusions of AS, in that, they do not support for the argument that shifts in inflation persistence coincide with changes in exchange rate regimes. Instead, they show that there are several other factors which are closely related to shifts in inflation persistence such as wars, oil price hikes and central bank reforms. Among these factors, the effects of oil price hikes in 1970's seem to have greater impact on shifts in inflation persistence.

Bleaney (2001) examines the same issue by using annual data for OECD countries for the period 1954 - 1999. He explains that degree of inflation persistence is highly sensitive to shifts in mean inflation, and therefore estimates of persistence can be biased upward or downward depending on the number of mean shifts allowed in the sample. His findings are contradictory to the findings of AS and Obstfeld, (1995).

\section{B. Inflation Persistence and the New Keynesian Phillips Curve (NKPC)}

The use of NKPC to describe inflation dynamics is quite common in recent literature. However, the standard purely forward looking NKPC is subject to severe criticism due to its inability to account for persistence in the inflation process. One of the early criticisms to the standard NKPC is put forth by Fuhrer and Moore (1995). More recently, Mankiw (2001) and, Rude and Whelan (2005) show that purely forward looking models cannot generate plausible results as it cannot relate to inertial nature of inflation. Due to these limitations of the standard NKPC, the use of the hybrid NKPC which incorporates both forward and backward looking elements has gained momentum.

In addition to the structural problem in the NKPC, there is another issue which relates to the driving variable of inflation process; whether it is the real marginal cost or a measure of output gap. Literature provides supportive evidence for both. The idea of using real marginal cost is pioneered by Gali and Gertler (1999), (2001- henceforth GG). Subsequently, this argument has been strengthened by Gali et al., (2001), (2005), Sbordone (2001), (2002), (2005), and several others. On the contrary, many authors report empirical evidence on the use of output gap measure, for example Roberts, (1995), (1997), (1998), Fuhrer and Moore (1995), Fuhrer (1997), Rudebusch (2002). Moreover, Linde (2005) estimates a hybrid NKPC by using standard measures of output gap and suggests that "backward-looking behaviour is about equally or more important than forward-looking behaviour in order to fit the data well" (p.1148).

Overall, despite the disagreements on the issues pertaining to the NKPC, it is widely used by researchers to describe the effects of past inflation and expected inflation on the current inflation. Several researchers attempt to extend the basic new Keynesian close economy model to describe open economy dynamics. However, the existing literature on new Keynesian models provides little evidence on explaining small open economy behaviour.
The present study, thus, evaluates the inflation persistence across exchange rate regimes in the context of a small open economy.

\section{The Model and Methodology}

\section{A. The Model}

The Phillips curve specification has been the focal point of many researches on modelling inflation dynamics. The present study also uses alternative specifications of the traditional Phillips curve and the new Keynesian Phillips curve (NKPC) in order to examine which specification may better explain the inflation process. Recently, the standard model for describing inflation dynamics has been the new Keynesian Phillips curve of the following form;

$$
\pi_{t}=\beta E_{t} \pi_{t+1}+\alpha x_{t}+v_{t}
$$

where $\pi_{t}$ is inflation rate, $x_{t}$ is output gap, $\beta$ measures the degree to which current inflation is determined by the expectations of future inflation, $E_{t}$ is expectations operator, and $v_{t}$ is exogenous shock to inflation process. However, as the standard NKPC does not have structural dependence of lagged inflation terms, many researchers now claim that it cannot account for inflation persistence. Therefore, due to empirical limitations of standard NKPC the present study adopts the hybrid Phillips curve specification which can be written as follows,

$$
\pi_{t}=\beta E \pi_{t} \pi_{t+1}+(1-\beta) \pi_{t-1}+\alpha_{x} x_{t}+v_{t}
$$

However, the hybrid specification of NKPC is also not free from criticism, as there is no consensus among researchers on determining the value of $\beta$. Ball (1999) sets $\beta=0$, so that current inflation is solely determined by past inflation, while McCallum (1997) uses $\beta=1$ so that current inflation depends on the expectations of future inflation. However, most of the researchers tend to assume $\beta$ to be less than one leaving some persistence in the inflation process. As the present study uses quarterly data, the basic form can be extended to:

$$
\pi_{t}=\beta E_{t} \pi_{t+4}+(1-\beta)\left(\alpha_{\pi 1} \pi_{t-1}+\alpha_{\pi 2} \pi_{t-2}+\alpha_{\pi 3} \pi_{t-3}+\alpha_{\pi 4} \pi_{t-4}\right)+\alpha_{x} x_{t-1}+u_{t}
$$

where $\beta E_{t} \pi_{t+4}$ relates to expectation of average inflation over the next year. Further, one-quarter lag is used in output gap and the one year-ahead inflation is based on information set at time $t$. In this specification, inflation persistence is measured by the sum of coefficients on lagged inflation terms. 


\section{B. Methodology}

Following Batini and Nelson (2001) this study adopts three definitions to examine inflation persistence, namely, (a) positive serial correlation in inflation (Type I inflation persistence), (b) lags between systematic monetary policy actions and their (peak) effects on inflation (Type II inflation persistence), and (c) lagged response to non-systematic policy actions - policy shocks (Type III inflation persistence). Batini (2002) and Kara and Nelson (2002) also use similar definitions.

Accordingly, type I inflation persistence is estimated using autocorrelation coefficient of price inflation process and different specifications of Phillips curve. Type II inflation persistence is examined using estimates of correlations between monetary policy measures and consumer price inflation. Type III inflation persistence is examined by using impulse response analysis.

\section{(i) Measuring Type I Inflation Persistence}

Type I inflation persistence relates to "a reduced form property of inflation" which can be represented by three factors, namely, "underlying pricing process, conduct of monetary policy, and expectation formation process of price setting agents," Batini and Nelson (2001). Various researchers adopt this definition in measuring inflation persistence including Fuhrer and Moore (1995), Taylor (2000), Cogley and Sargent (2001) and Sbordone (2002).

The price inflation process is specified as follows,

$$
\begin{aligned}
\Delta c p i_{t}= & \alpha_{0}+\sum_{i=1}^{4} \alpha_{1} \Delta c p i_{t-i}+\sum_{i=1}^{4} \alpha_{2} \Delta o i l_{t-i}+\sum_{i=1}^{4} \alpha_{3} \Delta i m p_{t-i} \\
& +\sum_{i=1}^{4} \alpha_{4} \Delta r e e r_{t-i}+\varepsilon_{t}
\end{aligned}
$$

where $\Delta c p i_{t}$ is change in the domestic price level (measured by the change of consumer price index: CPI $)^{3}$. To capture the effects of oil price shocks on domestic inflation, an 'oil inflation index' is included, and to take account of the impact of import price inflation on domestic consumer prices, an 'import price index' is used. Further, to capture the effects of exchange rate movements on domestic inflation, a term relating to change in the real (effective) exchange rate (reer) is included, which implies a depreciation of the real exchange rate improves competitiveness, thereby creating inflationary pressures on the domestic consumer prices. ${ }^{4}$ Accordingly, the expected sign of all the independent variables and the lagged inflation term is positive. $\varepsilon_{t}$ is the stochastic white noise error term. The term $\Delta c p i$ is of prime interest which explains the inertial nature of price inflation.

In order to examine possible shifts in price inflation process and how they may be reflected in corresponding shifts in the Phillips curve [as documented by AS (1991)], three alternative Phillips curve specifications are used. The reason to test different versions of the Phillips curve is motivated by the literature on both theory and empirics. The standard Phillips curve specification which is built upon closed economy assumptions is slightly modified to represent open economy characteristics by including terms relating to oil price inflation and import price inflation. Further, real exchange rate term is also included in consistent with various studies which examine open economy inflation dynamics [Ball (1999), Kara and Nelson (2002)].

\section{(a) Price-Based Phillips Curve:}

$$
\begin{aligned}
\Delta c p i_{t}= & \sum_{i=1}^{4} \gamma_{1} \Delta c p i_{t-i}+\sum_{i=1}^{8} \gamma_{2} \Delta \operatorname{gap}_{t-i}+\sum_{i=1}^{4} \gamma_{3} \Delta o i l_{t-i} \\
& +\sum_{i=1}^{4} \gamma_{4} \Delta i m p_{t-i}+\sum_{i=1}^{4} \gamma_{5} \Delta r e e r_{t-i}+v_{t}
\end{aligned}
$$

Interpretation of the variables is same as in the price inflation process. The output gap measure refers to the difference between actual output and the natural level of output. All variables enter with four lags, except for the output gap measure, as it is assumed to have effects on inflation well over a year. $v_{t}$ refers to stochastic disturbance term.

\section{(b) Standard New Keynesian Phillips Curve (NKPC):}

$$
\begin{aligned}
\Delta c p i_{t}= & \sum_{i=1}^{4} \eta_{1} E_{t} \Delta c p i_{t-i}+\sum_{i=1}^{8} \eta_{2} \Delta \operatorname{gap}_{t-i}+\sum_{i=1}^{4} \eta_{3} \Delta o i l_{t-i} \\
& +\sum_{i=1}^{4} \eta_{4} \Delta i m p_{t-i}+\sum_{i=1}^{4} \eta_{5}\left(\Delta \text { reer }_{t}-E_{t} \Delta r e e r_{t+i}\right)+v_{t}
\end{aligned}
$$

The standard NKPC defers from the price based Phillips curve on two counts. First, the term $E_{t} \Delta c p i_{t-i}$, which accounts for the impact of inflation expectations on current inflation. Because data series on inflation expectations is not available in Sri Lanka, an inflation forecast series is obtained by using the estimates of the price inflation process (equation 3.4). Of the options available to generate an inflation forecast, one-step ahead static forecasting is preferred to dynamic forecasting, because, the former uses actual values for lagged inflation rather than forecast values. Accordingly, equation 3.4 can be rearranged to represent the one-step ahead static forecasting process.

3/ See Appendix A for a detailed description of date series and sources.

4/ The procedure adopted in computing the real (effective) exchange series is shown in the data appendix. 


$$
\Delta \hat{c} p i_{t+i}=\hat{c}(1)+\hat{c}(2) \Delta o i l_{t+i}+\hat{c}(3) \Delta i m p_{t+i}+\hat{c}(4) \Delta r e e r_{t+i}+\hat{c}(5) \Delta c \hat{p} i_{t+i-1}
$$

Equation 3.7 assumes that $c p i_{t}$, is a function of past innovations $\left(\varepsilon_{t}, i \geq 0\right)$, due to stationarity and, therefore, $\varepsilon_{t+i}$ does not appear in equation 3.7, as it is uncorrelated with all observations.

Second, an openness condition $\left(\Delta\right.$ reer $_{t}-E_{t} \Delta$ reer $\left._{t+i}\right)$, is added to the standard closed economy NKPC specification followed by Kara and Nelson (2002). This relates to the difference between current real exchange rate depreciation relative to next period's expected real depreciation which accounts for the effects of changes in exchange rate depreciation on domestic consumer price inflation. Allsopp et al., (2006) use the standard NKPC model with a similar openness condition and highlight three features of this specification, $(a)$ movements in real exchange rate and inflation relative to their expected values are tightly related, $(b)$ incomplete exchange rate pass-through implies only a lower value of the coefficient $\eta_{5}$ in equation 3.6, but not the prediction of tight conditional relationship between the exchange rate and inflation, finally, $(c)$ implication of a tight relationship between nominal exchange rate and consumer price inflation, monetary policy rules. All other variables in equation 3.6 posit similar interpretation as above and $v_{t}$ refers to stochastic white noise disturbances.

\section{(c) Hybrid NKPC:}

$$
\begin{aligned}
& \Delta c p i_{t}=\sum_{i=1}^{4} \varphi_{1} E_{t} \Delta c p i_{t+i}+\sum_{i=1}^{4} \varphi_{2} \Delta c p i_{t-i}+\sum_{i=1}^{4} \varphi_{3} \Delta g a p_{t-i}+\sum_{i=1}^{4} \varphi_{4} \Delta o i l_{t-i} \\
& +\sum_{i=1}^{4} \varphi_{5} \Delta i m p_{t-i}+\sum_{i=1}^{4} \varphi_{6}\left(\Delta \text { reer }_{t}-E_{t} \Delta \text { reer }_{t+i}\right)+u_{t}
\end{aligned}
$$

All variables are defined as above, while $u$ refers to exogenous shocks which are assumed to be white noise. Thus, the hybrid version of NKPC combines the rational forward looking element with lagged inflation term which takes account of inertia in inflation. Lagged inflation term is the parameter of interest in each of the Phillips curve specification, as it explains the degree of inflation persistence. Accordingly, estimates are obtained for all these specifications and they are used to test for shifts in inflation persistence between regimes.

\section{(ii) Testing for Shifts in Inflation Persistence and Structural Breaks}

\section{(a) Recursive Estimates}

In order to identify shifts in inflation persistence, recursive estimates of the lagged inflation coefficient are obtained. Recursive estimates enable to trace evolution of coefficient on lagged price inflation as more data are used in the sample. A plot of recursive estimates on the lagged price inflation coefficient shows any structural breaks in the inflation generating process. Recursive estimates do not require a predetermined observation to be imposed in examining for structural breaks.

\section{(b) Chow Breakpoint Tests (Parameter Stability Tests)}

To examine the exact time of which the shift in inflation persistence takes place, Chow breakpoint tests are carried out. Breakpoint test uses the estimates of the price inflation process and Phillips curve specifications over the two regimes and examines whether there is significant parameter instability between them. Two test statistics are used in breakpoint tests namely, $F$-statistic and log likelihood ratio statistic. The $F$-statistic is obtained from the equation;

$$
\Delta m_{t}=\frac{\left(R S S_{R}-R S S_{U R}\right) / k}{\left(R S S_{U R}\right) /(T-2 k)}
$$

where $R S S_{R}$ is the residual sum of squares of the pooled regressions and $R S S_{U R}$ refers to the total of the residual sum of squares of the two regressions based on sub-samples. $T$ refers to the number of observations and $k$ refers to the number of parameters to be estimated. Alternatively, the log likelihood ratio statistic is based on the comparison between restricted and unrestricted maximum of the log likelihood function.

\section{(iii) Measuring Type II Inflation Persistence}

Type II inflation persistence relates to the time it takes for inflation to have peak response to change in monetary policy measures. Monetary policy measures considered in this study are growth in monetary aggregates, namely, $M_{1}, M_{2}$ and Reserve Money and the real interest rate.

\section{(a) Correlation Coefficient}

Type II inflation is estimated through the correlation coefficients between monetary policy measures and CPI inflation. The number of leads in money and inflation are correlated in order to identify the lag between change in money and peak response of inflation. The corresponding lag relates to the maximum coefficient in the correlation matrix is taken as a measure of type II inflation persistence.

\section{(b) Monetary Accommodation}

The degree of monetary accommodation is characterised by the following equation, 


$$
\begin{aligned}
\Delta m_{t}= & \gamma_{0}+\sum_{i=1}^{8} \gamma_{1} \Delta c p i_{t-i}+\sum_{i=1}^{8} \gamma_{2} \Delta i r_{t-i}+\sum_{i=1}^{8} \gamma_{3} \Delta g a p_{t-i} \\
& +\sum_{i=1}^{8} \gamma_{4} \Delta m_{t-i}+\mu_{t}
\end{aligned}
$$

where, measures the rate of money growth as proxied by alternative monetary aggregates i.e., log of narrow money supply $\left(M_{1}\right)$, log of money plus quasi-money series $\left(M_{2}\right)$ and Reserve Money. The explanatory variables used are lagged terms of consumer price inflation $\left(c p i_{t-i}\right)$, interest rate $\left(i r_{t-i}\right)$, growth of GDP $\left(g d p_{t-i}\right)$ and lagged dependent variable. The term $\mu$ refers to stochastic white noise disturbance term. Accordingly, equation 3.10 examines slope difference in the monetary reaction function between exchange rate regimes. The coefficient $(\gamma)$ measures the degree of monetary accommodation and is estimated by an autoregressive process with sufficient lags, as instruments.

\section{(iv) Measuring Type III Inflation Persistence}

Type III inflation persistence relates to lagged response of inflation to policy shocks (non-systematic policy actions). In order to identify inflation response to policy shocks under different exchange rate regimes, a system of equations is estimated using vector autoregressive-unrestricted (VAR) method. The VAR specification stated below embraces the characteristics of an open economy model. The theoretical underpinning of the model draws to a greater extent to the model suggested by Ball (1999). Ball's model consists of an open economy IS curve, an open economy Phillips curve and an equation linking interest rate and exchange rate. The IS curve is formed by real output variable which depends lags of interest rate, exchange rate, and lagged output and demand shocks. The open economy Phillips curve which explains inflation process, depends on lagged output, change in exchange rate and random shocks. Further, interest rate and the exchange rate are used as policy rules as chosen by the central bank

Accordingly, the variables used in VAR include log of real output, log of consumer price inflation, interest rate, and log of real exchange rate. In order to identify inflation response to policy shocks, monetary aggregates and short term interest rates are used. Further, to account for price shocks, $\log$ of oil price inflation is included as an exogenous variable. The VAR system is specified as follows;

$$
\begin{array}{ll}
\Delta g d p_{t} & =\alpha_{1} \Delta g d p_{t-i}+\alpha_{2} \Delta c p i_{t-i}+\alpha_{3} \Delta i r_{t-i}+\alpha_{4} \Delta r e e r_{t-i}+\varepsilon_{1 t} \\
\Delta c p i_{t} & =\beta_{1} \Delta g d p_{t-i}+\beta_{2} \Delta c p i_{t-i}+\beta_{3} \Delta i r_{t-i}+\beta_{4} \Delta r e e r_{t-i}+\varepsilon_{2 t} \\
\Delta i r_{t} & =\chi_{1} \Delta g d p_{t-i}+\chi_{2} \Delta c p i_{t-i}+\chi_{3} \Delta i r_{t-i}+\chi_{4} \Delta r e e r_{t-i}+\varepsilon_{3 t} \\
\Delta r e e r_{t} & =\delta_{1} \Delta g d p_{t-i}+\delta_{2} \Delta c p i_{t-i}+\delta_{3} \Delta i r_{t-i}+\delta_{4} \Delta r e e r_{t-i}+\varepsilon_{4 t}
\end{array}
$$

This system of equations relates to the operating characteristics of a stationary autoregression with white noise shocks. The order of the VAR system is determined by the lag selection criteria. In this study, no attempt is made to interpret the individual VAR coefficients as they provide only little information on the overall effect of changes in policy measures on inflation. The Impulse Response Functions are generated through innovations to short term interest rate, change in monetary aggregates $M_{1}, M_{2}$ and Reserve Money. The main interest is on the responses of consumer price inflation to shocks in monetary policy measures.

\section{Findings and Analysis}

The empirical findings with regard to inflation persistence across fixed and flexible exchange rate regimes are discussed here. First, the estimates of type I inflation persistence are presented as modelled by price inflation process and various Phillips curve specifications. Results of recursive estimates and parameter stability tests are also discussed. Second, estimates of type II inflation persistence are discussed as measured by correlation between money and inflation, as well as by monetary accommodation coefficients. Finally, results of type III inflation persistence are discussed by means of impulse response functions of an unrestricted VAR system.

\section{A. Summary of Descriptive Statistics}

In order to examine basic features of data series used in the study, descriptive statistics are computed. Table 4.1 presents a summary of descriptive statistics of all the data series. The mean and the standard deviation of each variable are shown for the entire sample period as well as for each regime, separately. Consumer price inflation shows a dramatic shift in mean inflation (about 7.50 percentage point) between the regimes, while the shift in the standard deviation is about a 1.91. Import price inflation and oil price inflation also show an increase in both measures, but the magnitude is small. Particularly, oil price inflation shows a larger shift in standard deviation in the flexible regime. Similarly, all other series show an increase in both mean and standard deviation across regimes. 
Table 4.1 - Descriptive Statistics of Data Series

\begin{tabular}{|c|c|c|c|c|c|c|}
\hline \multirow[b]{2}{*}{ Series } & \multicolumn{3}{|c|}{ Mean } & \multicolumn{3}{|c|}{ Standard Deviation } \\
\hline & $\begin{array}{l}\text { Full Sample } \\
\text { Period } \\
\text { (1960Q1 to } \\
\text { 2005Q4) }\end{array}$ & $\begin{array}{c}\text { Fixed } \\
\text { Regime } \\
\text { (1960Q1 to } \\
1977 Q 3)\end{array}$ & $\begin{array}{l}\text { Flexible } \\
\text { Regime } \\
\text { (1977Q4 to } \\
\text { 2005Q4) }\end{array}$ & $\begin{array}{l}\text { Full Sample } \\
\text { Period } \\
\text { (1960Q1 to } \\
\text { 2005Q4) }\end{array}$ & $\begin{array}{c}\text { Fixed } \\
\text { Regime } \\
(1960 Q 1 \text { to } \\
\text { 1977Q3) }\end{array}$ & $\begin{array}{c}\text { Flexible } \\
\text { Regime } \\
\text { (1977Q4 to } \\
\text { 2005Q4) }\end{array}$ \\
\hline$\Delta$ cpil & 8.4412 & 3.8322 & 11.3371 & 6.3076 & 3.8917 & 5.7978 \\
\hline$\Delta$ oil & 3.6174 & 2.4175 & 5.5544 & 27.4243 & 15.6512 & 39.7493 \\
\hline$\Delta$ imp & 2.9694 & 2.8229 & 3.0601 & 5.0381 & 5.6779 & 4.6221 \\
\hline $\mathrm{ir}^{*}$ & 10.1380 & 5.4718 & 13.0961 & 4.6505 & 1.3625 & 3.3963 \\
\hline reir* & 8.1330 & 4.5658 & 10.3625 & 4.1342 & 1.5166 & 3.6607 \\
\hline exrate $^{*}$ & 32.4104 & 5.8026 & 49.1286 & 30.3852 & 1.1395 & 27.8735 \\
\hline$\Delta$ exrate & 1.8651 & 0.9643 & 2.4231 & 6.8720 & 4.8309 & 7.8448 \\
\hline reer* ${ }^{*}$ & 71.2536 & 31.4262 & 96.2779 & 32.2431 & 5.3107 & 6.6087 \\
\hline$\Delta$ reer & 1.0224 & 1.2566 & 0.8774 & 9.1535 & 7.5469 & 10.0504 \\
\hline$\Delta r$ rmoney & 3.1137 & 2.5884 & 3.7345 & 5.9170 & 7.1386 & 4.9903 \\
\hline$\Delta \mathrm{m} 1$ & 2.9990 & 2.1434 & 3.5337 & 4.5565 & 3.8164 & 4.9042 \\
\hline$\Delta \mathrm{m} 2$ & 3.6875 & 2.4794 & 4.4426 & 3.7167 & 3.2000 & 3.8293 \\
\hline$\Delta g d p$ & 1.1918 & 0.9425 & 1.3462 & 3.7847 & 0.5907 & 4.7957 \\
\hline No. of Observations & 184 & 71 & 113 & 184 & 71 & 113 \\
\hline
\end{tabular}

Notes: * refers to series which are in levels, while others are in log differences.

All series are in logs except for ir ${ }^{\star}$ and reir*. Data definitions and sources are in the Appendix A.

\section{B. Unit Root Tests}

Time series data often tend to be trended. In order to avoid spurious regressions resulted from time trended data, it is common to test for stationarity of data series. Therefore, as the first step, Unit Root Tests are carried out for all the data series using Augmented Dickey Fuller (ADF) method. Results are reported in Table 4.2. First, all the series (seasonally adjusted) are tested for unit roots at levels, before and after taking logs (the interest rate series are not logged). Results show that all the data series except the real interest rate (reir) and output gap (gap) are non-stationary at levels, before and after logged. Therefore, log difference is obtained for these series. The log differenced series are stationary, $\mathrm{I}(0)$, at conventional significance levels. The results are also confirmed by the Phillips-Perron test.
Table 4.2 - Results of the Augmented Dickey-Fuller (ADF) Test for Unit Roots

\begin{tabular}{|c|c|c|c|c|c|c|}
\hline \multirow[t]{2}{*}{ Series } & \multicolumn{2}{|c|}{$\begin{array}{l}\text { Levels } \\
\quad 1\end{array}$} & \multicolumn{2}{|c|}{$\begin{array}{c}\text { Log Levels } \\
\text { II }\end{array}$} & \multicolumn{2}{|c|}{$\begin{array}{c}\text { Log Difference } \\
\text { III }\end{array}$} \\
\hline & T-statistic & No. of Lags & T-statistic & No. of Lags & T-statistic & No. of Lags \\
\hline$\Delta \mathrm{cpi}$ & $\begin{array}{c}5.1201 \\
(1.0000)\end{array}$ & 11 & $\begin{array}{c}3.3221 \\
(1.0000)\end{array}$ & 4 & $\begin{array}{l}-3.8945^{*} \\
(0.0026)\end{array}$ & 4 \\
\hline$\Delta$ imp & $\begin{array}{l}-1.9432 \\
(0.6267)\end{array}$ & 1 & $\begin{array}{l}-0.9974 \\
(0.9408)\end{array}$ & 2 & $\begin{array}{l}-4.4804^{*} \\
(0.0003)\end{array}$ & 1 \\
\hline$\Delta$ oil & $\begin{array}{l}-1.7552 \\
(0.7259)\end{array}$ & 1 & $\begin{array}{l}-1.707 \\
(0.748)\end{array}$ & 4 & $\begin{array}{l}-6.2632^{\star} \\
(0.0000)\end{array}$ & 4 \\
\hline ir & $\begin{array}{l}-2.6541 \\
(0.2574)\end{array}$ & 4 & -- & & $\begin{array}{l}-6.6921^{*} \\
(0.0000)\end{array}$ & 4 \\
\hline reir & $\begin{array}{l}-3.1865^{* *} \\
(0.0432)\end{array}$ & 2 & -- & & -- & \\
\hline gdp & $\begin{array}{c}1.2032 \\
(1.0000)\end{array}$ & 5 & $\begin{array}{l}1.2178 \\
(1.0000)\end{array}$ & 5 & $\begin{array}{l}-7.1302^{*} \\
(0.0000)\end{array}$ & 2 \\
\hline exrate & $\begin{array}{c}2.3328 \\
(1.0000)\end{array}$ & 4 & $\begin{array}{l}-0.9271 \\
(0.9496)\end{array}$ & 4 & $\begin{array}{l}-7.1909^{*} \\
(0.0000)\end{array}$ & 4 \\
\hline reer & $\begin{array}{l}-1.3645 \\
(0.5998)\end{array}$ & 4 & $\begin{array}{l}-1.5912 \\
(0.793)\end{array}$ & 4 & $\begin{array}{l}-6.1270^{*} \\
(0.0000)\end{array}$ & 4 \\
\hline gap & -- & & $\begin{array}{l}-5.50^{*} \\
(0.0000)\end{array}$ & 4 & -- & \\
\hline$\Delta$ rmoney & $\begin{array}{c}5.4408 \\
(1.0000)\end{array}$ & 1 & $\begin{array}{l}-1.956 \\
(0.6497)\end{array}$ & 1 & $\begin{array}{r}-16.4412^{\star} \\
(0.0000)\end{array}$ & 4 \\
\hline$\Delta \mathrm{m} 1$ & $\begin{array}{c}3.3802 \\
(1.0000)\end{array}$ & 10 & $\begin{array}{l}-2.4385 \\
(0.3646)\end{array}$ & 12 & $\begin{array}{l}-5.0412^{*} \\
(0.0000)\end{array}$ & 3 \\
\hline$\Delta \mathrm{m} 2$ & $\begin{array}{c}2.2378 \\
(1.0000)\end{array}$ & 13 & $\begin{array}{l}-2.4321 \\
(0.3650)\end{array}$ & 4 & $\begin{array}{l}-3.7901^{*} \\
(0.0035)\end{array}$ & 3 \\
\hline
\end{tabular}

Notes: Mackinnon critical values for rejection of hypothesis of a unit root are used. ${ }^{*}{ }^{* *}$, and ${ }^{* * *}$ indicate significance levels at $1 \%, 5 \%$ and $10 \%$ respectively. P-values are presented in parentheses. The optimal lag length based on SIC criterion is presented. For variables ir, reir, exrate, reer, and oil 'user specified' lag lengths are used. Further, ir, reir, exrate, and reer are tested only with a constant (without a trend) and other series are tested constant with a trend. The series ir and reir are not in logs

\section{Estimates of Type I Inflation Persistence}

This section describes the estimates of price inflation process and Phillips curve specifications, with more emphasis on lagged inflation coefficient which relates to degree of inflation persistence. First, results of price inflation process are described, followed by a discussion on recursive estimates of lagged price inflation coefficient. Results of Chow parameter stability tests are described next. Second, estimates of Phillips curve specifications are presented with a discussion on recursive estimates and breakpoint tests in the context of shifts in inflation persistent across exchange rate regimes. 


\section{(i) Price Inflation Process}

Price inflation process includes lags of consumer price inflation, oil price inflation, real import price inflation and real effective exchange rate. The ordinary least squares (OLS) estimates of the price inflation process (equation 3.4) are presented in Table 4.3, for the whole sample period as well as for each regime, separately. Inflation persistence is measured by lagged price inflation coefficient which is about 46.95 per cent for the full sample period with only the first quarter lag being statistically significant. Results show an increase in inflation persistence between the regimes but the change is small (about 4.01 percentage points).

The impact of oil price inflation on domestic consumer price inflation is significant after 2 lags but its magnitude is small. This may be due to the deficiencies in the CPI index $(1952=100)$ used, which bears only smaller weight on fuel (4.30 per cent) and, moreover,

\section{Table 4.3 - Estimates of Consumer Price Inflation Process}

\section{Dependant Variable: Consumer Price Inflation}

\begin{tabular}{lccc}
\multicolumn{4}{c}{$\Delta c p i_{t}=\alpha_{0}+\sum_{i=1}^{4} \alpha_{1} \Delta c p i_{t-i}+\sum_{i=1}^{4} \alpha_{2} \Delta o i l_{t-i}+\sum_{i=1}^{4} \alpha_{3} \Delta i m p_{t-i}+\sum_{i=1}^{4} \alpha_{4} \Delta r e e r_{t-i}+\varepsilon_{t}$} \\
\hline Independent Variable & $\begin{array}{c}\text { Full } \\
\text { Sample } \\
\text { Period } \\
\text { (I) }\end{array}$ & $\begin{array}{c}\text { Fixed } \\
\text { Exchange Rate } \\
\text { Regime }\end{array}$ & $\begin{array}{c}\text { Flexible } \\
\text { Exchange Rate } \\
\text { Regime }\end{array}$ \\
\hline Constant & 0.0063 & 0.0029 & 0.0135 \\
& $(0.0022)$ & $(0.0020)$ & $(0.0044)$ \\
$\Delta$ cpi & $0.4695(1)$ & $0.3734(1)$ & $0.4135(1)$ \\
& $(0.0801)$ & $(0.1489)$ & $(0.1063)$ \\
$\Delta$ oil & $0.0201(2)$ & $0.0176(2)$ & $0.0225(2)$ \\
& $(0.0083)$ & $(0.0092)$ & $(0.0129)$ \\
$\Delta$ imp & $0.0814(3)$ & - & $0.1462(3)$ \\
& $(0.0405)$ & & $(0.0178)$ \\
$\Delta$ reer & $0.0353(3)$ & - & $0.0500(1)$ \\
& $(0.0179)$ & & $(0.0274)$ \\
\hline No. of Observations (after adjusting end points) & 117 & 64 & 113 \\
Durbin-Watson Statistic & 1.98 & 1.91 & 1.99 \\
Serial Correlation (LM Test) & 0.62 & 0.67 & 0.52 \\
R-Squared & 0.36 & 0.53 & 0.32 \\
\hline
\end{tabular}

R-Squared

1. Asymptotic standard errors are in parentheses below the estimated coefficients. Four lags of each variable are used as instruments Only the statistically significant lags are reported with the lag number in parentheses besides the coefficient.

2. The Breusch-Godfrey Lagrange multiplier test is the most appropriate for testing serial correlation when the lagged dependent variables exist in the right hand side of the regression. The probability value for rejecting the null hypothesis dependent variables exist in the right
of no serial correlation is reported. the prices are administered by the government. (An alternative consumer price index does not exit for the entire sample period in quarterly frequency).

The real import price inflation which can partly account for oil price changes, is significant after three lags, and the magnitude is larger, compared to oil price inflation. The effect of import price inflation on consumer prices has been about 14.62 per cent in the flexible regime, while in the fixed regime none of the lags appears to be significant at conventional significance levels. The inclusion of real exchange rate in the price inflation process improves overall significance of the regression even though its impact seems to be minimal, also the coefficients are only weakly significant.

Further, in order to test for evidence of a shift in inflation persistence, recursive estimates of lagged inflation coefficient are obtained without imposing a predetermined date (observation) for a possible structural break. Figure 4.1 shows a plot of the recursive estimates, which, in general, ignores some observations in the first few years. As shown in the figure, there is some evidence of a structural break in late 1970s and it is more apparent during the year 1979/80. As described earlier, the period starting from late 1970s up until late 1980s has been very significant for Sri Lanka, in many ways. During that period major economic and institutional changes occurred, specially, the year 1977 is considered as a breakpoint for many reasons. Introduction of open economic policies which includes current account liberalization, switching from fixed exchange rate to managed exchange rate, and establishment of new constitution for the country which lead to redefining the role of economic policy for price controls, wage bargaining and fiscal policy stance etc. Therefore, it is far from clear, at this stage, that the evidence of structural break can solely be attributed to the regime change, because of several changes introduced in macroeconomic policy stance in Sri Lanka during that period.

Figure 4.1 - Recursive Estimates of Lagged Price Inflation Coefficient of Price Inflation Process

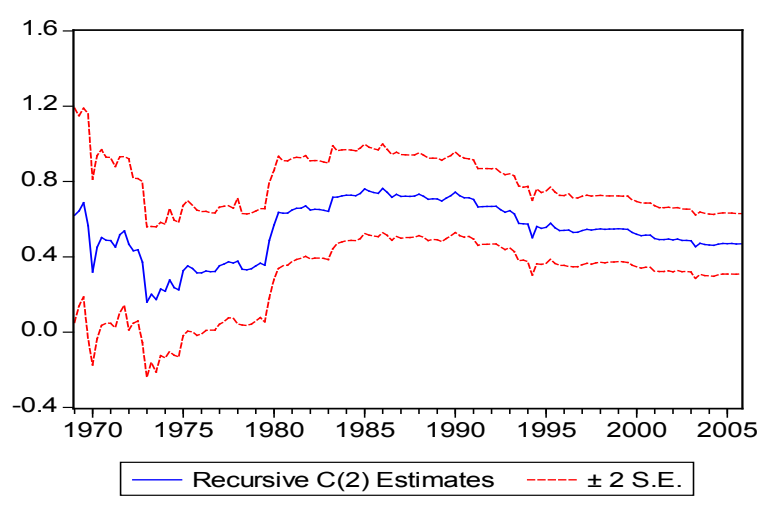




\section{Table 4.4 - Chow Breakpoint Tests of Price Inflation Process}

\begin{tabular}{lcccc}
\hline & \multicolumn{4}{c}{ Breakpoints } \\
\cline { 2 - 5 } & $\mathbf{1 9 7 7 Q 4}$ & $\mathbf{1 9 7 8 Q 1}$ & $\mathbf{1 9 7 9 Q 1}$ & $\mathbf{1 9 8 0 Q 1}$ \\
\hline F-statistic & 1.5695 & 1.6917 & 1.9001 & 1.7092 \\
& $(0.0798)$ & $(0.0505)$ & $(0.0223)$ & $(0.0473)$ \\
Log likelihood ratio & 30.2815 & 32.4342 & 36.0477 & 32.7419 \\
& $(0.0243)$ & $(0.0133)$ & $(0.0045)$ & $(0.0121)$ \\
\hline
\end{tabular}

Note: The probability values are presented in parenthesis below the computed test statistics.

In order to examine whether the shift in inflation exactly coincides with the period of regime change, Chow breakpoints tests are carried out. Chow test assumes that there is parameter stability during the full sample period and therefore, the null hypothesis is set out as the estimates reported in columns II and III in Table 4.3 are statistically the same. Results are presented in Table 4.4. For this test, four observation points are used during the period of economic liberalization. The first point (1977Q4) relates to the period of regime change and, others are subsequent periods which may capture any lag effect in the adjustment process followed by the policy change.

As Table 4.4 shows, there is evidence of structural break during the period of regime change. The null hypothesis of no structural break is rejected at 5 percent significance level by the Log Likelihood ratio, while at 10 per cent level by the F-statistic. However, the observation point which relates to the quarter immediately after the regime change becomes significant at 5 percent level as indicated by both test statistics. Further, evidence on structural breaks is more apparent in the year 1979/80, which may, perhaps, be due to the accumulated effects of various policy changes introduced during that period. On the other hand, this suggests a gradual adjustment process of inflation expectations of public, as they perceive inflation to be high followed by the regime change.

Overall, there is substantial evidence of parameter instability in the estimates of consumer price inflation process before and after the regime change. In the remainder of this section, this evidence is re-examined with estimated parameters of different Phillips curve specifications.

\section{(ii) Price Based Open Economy Phillips Curve}

In order to identify whether shifts in consumer price inflation process seem to generate corresponding shifts in parameters of the Phillips curve, three open economy Phillips curve specifications are used, namely, the traditional price-based Phillips curve (purely backward looking), the standard new Keynesian Phillips curve (NKPC - purely forward looking), and the hybrid NKPC (incorporating both forward and backward looking elements). The OLS

\section{Table 4.5 - Estimates of Open Economy Price-Based Phillips Curve}

\begin{tabular}{|c|c|c|c|}
\hline \multicolumn{4}{|c|}{$\begin{array}{l}\text { Dependant Variable: Consumer Price Inflation } \\
\qquad \begin{array}{c}\Delta c p i_{t}=\sum_{i=1}^{4} \gamma_{1} \Delta c p i_{t-i}+\sum_{i=1}^{8} \gamma_{2} \Delta g a p_{t-i}+\sum_{i=1}^{4} \gamma_{3} \Delta o i l_{t-i} \\
+\sum_{i=1}^{4} \gamma_{4} \Delta i m p_{t-i}+\sum_{i=1}^{4} \gamma_{5} \Delta r e e r_{t-i}+v_{t}\end{array}\end{array}$} \\
\hline Independent Variable & $\begin{array}{l}\text { Full } \\
\text { Sample } \\
\text { Period } \\
\text { (I) }\end{array}$ & $\begin{array}{l}\text { Fixed } \\
\text { Exchange Rate } \\
\text { Regime } \\
\text { (II) }\end{array}$ & $\begin{array}{l}\text { Flexible } \\
\text { Exchange Rate } \\
\text { Regime } \\
\text { (III) }\end{array}$ \\
\hline$\Delta \mathrm{cpi}$ & $\begin{array}{l}0.4782(1) \\
(0.0809)\end{array}$ & $\begin{array}{l}0.3966(1) \\
(0.1672)\end{array}$ & $\begin{array}{l}0.4041(1) \\
(0.1099)\end{array}$ \\
\hline gap & $\begin{array}{l}0.6481(7) \\
(0.2748)\end{array}$ & - & $\begin{array}{l}0.5823(7) \\
(0.3551)\end{array}$ \\
\hline$\Delta$ oil & $\begin{array}{l}0.0196(2) \\
(0.0211)\end{array}$ & $\begin{array}{l}0.0226(2) \\
(0.0107)\end{array}$ & -- \\
\hline$\Delta$ imp & $\begin{array}{l}0.0824(3) \\
(0.0417)\end{array}$ & -- & $\begin{array}{l}0.1446(3) \\
(0.0625)\end{array}$ \\
\hline$\Delta$ reer & $\begin{array}{l}0.0351(3) \\
(0.0180)\end{array}$ & -- & $\begin{array}{l}0.0551(3) \\
(0.0283)\end{array}$ \\
\hline No. of Observations (after adjusting end points) & 176 & 63 & 113 \\
\hline Durbin-Watson Statistic & 1.99 & 1.92 & 1.99 \\
\hline Serial Correlation (LM Test) & 0.46 & 0.61 & 0.52 \\
\hline R-Squared & 0.40 & 0.60 & 0.36 \\
\hline
\end{tabular}

Notes:

1. Asymptotic standard errors are in parentheses below the estimated coefficients. Four lags of each variable are used as instruments Only the statistically significant lags are reported.

2. The Breusch-Godfrey Lagrange multiplier test and the Durbin-Watson statistic are used to test serial correlation. The probability value for rejecting the null hypothesis of no serial correlation is reported.

estimates of the price based Phillips curve (equation 3.5) are presented in Table 4.5, for the full sample period and each regime as well.

Results are almost identical to the estimates obtained for the consumer price inflation process. Overall, inflation persistence during the full sample period is marked at 47.82 pe cent, while fixed and flexible regimes report 39.66 and 40.41 per cent, respectively. The shift in inflation persistence across regimes is 0.75 per cent which is borderline. Estimates of output gap measure ${ }^{5}$ is in expected sign and becomes significant after seven lags. However, none of the lags of output gap measure becomes statistically significant in the fixed regime. Output

5/ Output gap measure is computed as the difference between log of real GDP (seasonally Adjusted) and the long-term trend output as obtained from the Hodrick-Prescott (HP) filter, using the smoothing parameter 1600 to represent quarterly frequency of data. 
Figure 4.2 - Recursive Estimates of Lagged Price Inflation Coefficient in Open Economy Price-Base Phillips Curve

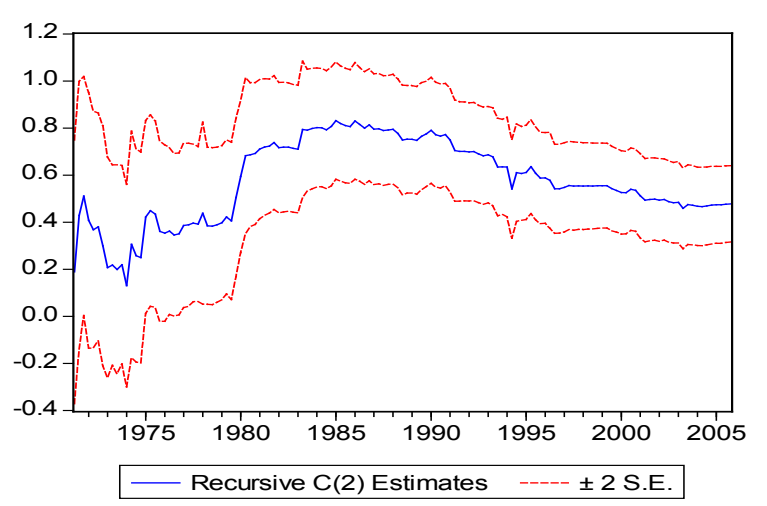

gap measure seems to yield better results in the flexible regime despite contrasting views among researchers. Effects of oil price inflation seem to be marginal, which may, perhaps, be due to data limitations as described in the previous section. Impact of real import price inflation is significant only in the flexible regime (14.46 per cent) and it enters as significant after three lags. Further, real effective exchange rate becomes significant only in the flexible regime but its impact on inflation is low.

Because the main focus of the paper is on shifts of inflation persistence parameter, recursive estimates of lagged inflation coefficient are obtained and results are plotted in Figure 4.2. Similar results are observed as in the price inflation process which provide evidence of a shift in inflation persistence in late 1970s and it is more apparent during the year 1979/80.

In order to identify exact point of time the shift occurs, Chow breakpoint tests are carried out in the similar fashion, as described above. Chow test examines whether there is a significant difference between estimates reported in columns II and III in Table 4.5. Results are shown to be mixed as reported in Table 4.6. While the $F$-statistic cannot reject the null

Table 4.6 - Chow Breakpoint Tests of Open Economy Price-Base Phillips Curve

\begin{tabular}{lcccc}
\hline & \multicolumn{4}{c}{ Breakpoints } \\
\cline { 2 - 5 } & $\mathbf{1 9 7 7 Q 4}$ & $\mathbf{1 9 7 8 Q 1}$ & $\mathbf{1 9 7 9 Q 1}$ & $\mathbf{1 9 8 0 Q 1}$ \\
\hline F-statistic & 1.1021 & 1.1450 & 1.2462 & 1.1902 \\
& $(0.3501)$ & $(0.3046)$ & $(0.2135)$ & $(0.2611)$ \\
Log likelihood ratio & 34.8055 & 36.0306 & 38.8862 & 37.3117 \\
& $(0.0918)$ & $(0.0711)$ & $(0.0378)$ & $(0.0539)$ \\
\hline
\end{tabular}

Note: The probability values are presented in parenthesis below the computed test statistics. hypothesis of no structural break at any conventional significance levels for any observation point, the Log Likelihood ratio provides evidence of a structural break during the period of regime shift (1977Q4) at 10 per cent significance level. Further, there is strong evidence of a structural break during the period after about a one year of the regime change, implying gradual adjustment process of inflation expectations, followed by the policy change.

\section{(iii) Open Economy New Keynesian Phillips Curve (NKPC)}

As described above, NKPC is defined; current inflation as a function of next period's expected inflation and deviation of lagged output from its potential level. Inflation expectations are proxied by an inflation forecast generated using the one-step ahead static forecasting method. As described, the estimates of price inflation process (equation 3.4) are used to generate inflation forecast series. A plot of the inflation forecast series is shown in Figure 4.3. Of the options available to generate inflation forecast, the static forecasting is more accurate than dynamic forecasting, because it uses actual lagged inflation values rather than forecasted values. A plot of the actual and fitted values are shown in Figure 4.4, while Figure 4.5 shows the deviation of inflation forecast from the actual inflation, which indicates larger variations during the flexible regime.

In order to verify robustness of the forecast series, a forecast evaluation is conducted. Results are shown in Table 4.7. The smaller values of the Root Mean Squared Error (RMSE) and Mean Absolute Error (MAE) statistics provide evidence of better fit of the forecast series. Further, the smaller values of the Theil Inequality Coefficient which lies between zero and one and, the Bias Proportion which indicates how far the mean of the forecast deviates from that of actual series, reassure the accuracy of the forecast. Moreover, smaller variance proportion indicates that the actual series is well represented by the forecast series.
Figure 4.3 - Inflation Forecast Series (One-Step Ahead Static Forecasting)

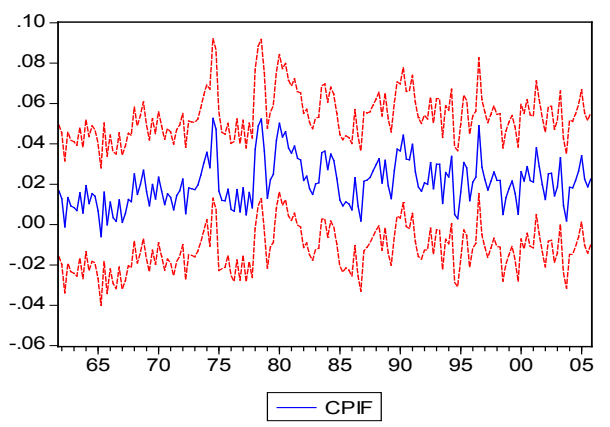

Figure 4.4 - Actual and Forecasted Inflation Series

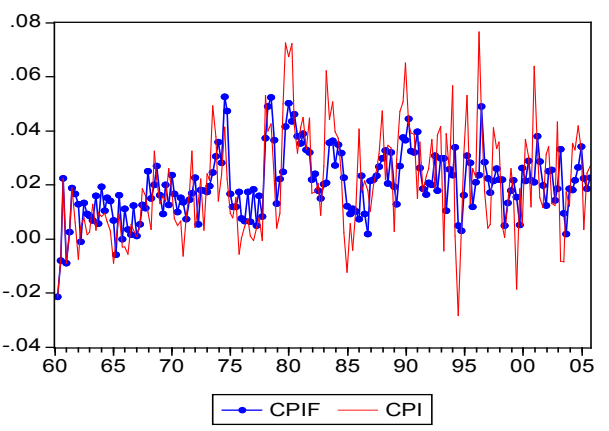




\section{Figure 4.5 - Deviation of Inflation Forecast from Actual Inflation}

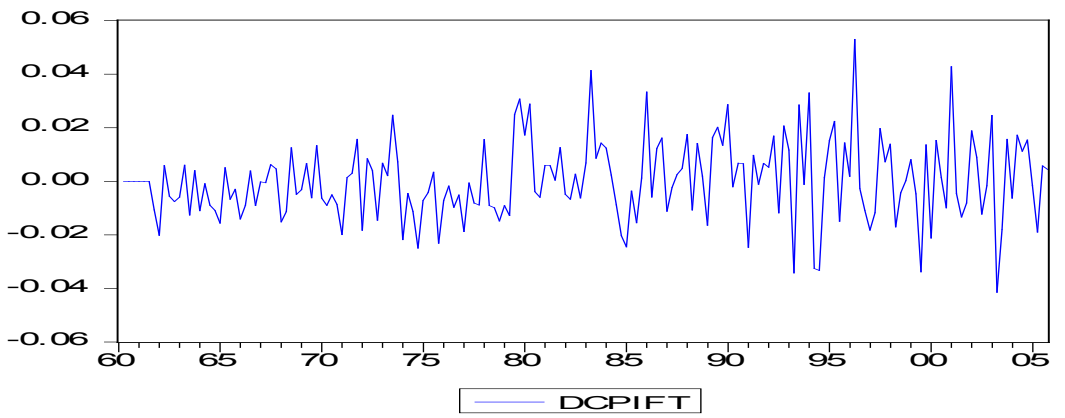

\section{Table 4.7 - Results of Inflation Forecast Evaluation}

\begin{tabular}{lr}
\hline Forecast Series: CPIF & \\
Actual Series: CPI & 0.015200 \\
\hline Root Mean Squared Error & 0.011918 \\
Mean Absolute Error & 164.2696 \\
Mean Absolute Percentage Error & 0.292403 \\
Theil Inequality Coefficient & 0.000000 \\
$\quad$ Bias Proportion & 0.247066 \\
$\quad$ Variance Proportion & 0.752934 \\
$\quad$ Covariance Proportion & \\
Sample Period : 1961Q4 to 2005Q4 & 177 \\
No. of Observation: & \\
\hline
\end{tabular}

Estimates of the open economy standard NKPC specification are shown in Table 4.8 Results need to be interpreted cautiously. Coefficient on the expected inflation term is near unity for the full sample period suggesting the importance of accounting for inflation expectations in modelling inflation dynamics. However, the standard purely forward looking NKPC provides no evidence of inflation inertia due to non-existence of structural dependence of inflation. Output gap coefficient becomes significant after seven lags in both full sample period and the flexible regime period indicating that it takes nearly two years to have impact on price inflation. However, none of the output gap coefficients turns out to be statistically significant in the fixed regime.

None of the terms in oil price inflation is statistically significant at the conventional significance levels. However, dropping oil price inflation from the regression does not seem to improve explanatory power of the regression. Real import price inflation yields a positive but smaller impact while expected depreciation in real exchange rate shows a significant impact in the flexible regime period which is about 39.71 per cent. This implies

\section{Table 4.8 - Estimates of Open Economy New Keynesian Phillips Curve (NKPC)} Dependant Variable: Consumer Price Inflation

$$
\begin{aligned}
\Delta c p i_{t}= & \sum_{i=1}^{4} \eta_{1} E_{t} \Delta c p i_{t-i}+\sum_{i=1}^{8} \eta_{2} \Delta \text { gap }_{t-i}+\sum_{i=1}^{4} \eta_{3} \Delta o i l_{t-i} \\
& +\sum_{i=1}^{4} \eta_{4} \Delta i m p_{t-i}+\sum_{i=1}^{4} \eta_{5}\left(\Delta r e e r_{t}-E_{t} \Delta r e e r_{t+i}\right)+v_{t}
\end{aligned}
$$

\begin{tabular}{|c|c|c|c|c|c|c|}
\hline Independent Variable & \multicolumn{2}{|c|}{$\begin{array}{l}\text { Full } \\
\text { Sample } \\
\text { Period } \\
\text { (I) }\end{array}$} & $\begin{array}{c}\text { Fixed } \\
\text { Exchange Rate } \\
\text { Regime } \\
\text { (II) }\end{array}$ & \multicolumn{3}{|c|}{$\begin{array}{l}\text { Flexible } \\
\text { Exchange Rate } \\
\text { Regime } \\
\text { (III) }\end{array}$} \\
\hline$\Delta$ cpif & \multicolumn{2}{|c|}{$\begin{array}{l}1.0927(3) \\
(0.2630)\end{array}$} & $\begin{array}{l}0.4630(4) \\
(0.0586)\end{array}$ & $\begin{array}{l}1.1184(1) \\
(0.0504)\end{array}$ & $\begin{array}{l}1.3229(3) \\
(0.0017)\end{array}$ & $\begin{array}{l}-0.8789(4) \\
(0.027)\end{array}$ \\
\hline gap & \multicolumn{2}{|c|}{$\begin{array}{l}0.5445(7) \\
(0.2183)\end{array}$} & & $\begin{array}{l}0.5462(7) \\
(0.2802)\end{array}$ & & \\
\hline$\Delta$ imp & $\begin{array}{l}0.0774(1) \\
(0.0462)\end{array}$ & $\begin{array}{l}0.0753(3) \\
(0.0382)\end{array}$ & - & - & - & - \\
\hline 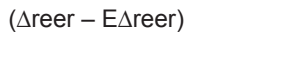 & $\begin{array}{l}0.0606(1) \\
(0.0149)\end{array}$ & $\begin{array}{l}0.0577(3) \\
(0.0193)\end{array}$ & - & $\begin{array}{l}0.1298(1) \\
(0.0240)\end{array}$ & $\begin{array}{l}0.1318(2) \\
(0.0424)\end{array}$ & $\begin{array}{l}0.1292(3) \\
(0.0455)\end{array}$ \\
\hline \multicolumn{7}{|l|}{ No. of Observations } \\
\hline Durbin-Watson Statistic & \multicolumn{2}{|c|}{1.94} & 2.02 & \multicolumn{3}{|c|}{1.82} \\
\hline Serial Correlation (LM Tes & \multicolumn{2}{|c|}{0.74} & 0.84 & \multicolumn{3}{|c|}{0.84} \\
\hline R-Squared & \multicolumn{2}{|c|}{0.42} & 0.58 & \multicolumn{3}{|c|}{0.48} \\
\hline
\end{tabular}

Notes:

1. Asymptotic standard errors are in parentheses below the estimated coefficients. Four leads of expected inflation and four lags of every other variables are used as instruments. Only the statistically significant lags are reported. The lag/lead number is indicated besides the coefficient estimate.

2. The model includes an autoregressive error term to account for serial correlation. The Durbin-Watson statistic and Breusch-Godfrey Lagrange multiplier test results are shown after inclusion of the error term. The probability value for rejecting the null hypothesis of no serial correlation is reported.

a fairly quicker pass-through effect in the flexible regime which results in tight relationship between real exchange rate movements and inflation. A possible channel through which this effect takes place is that an increase in activity followed by a depreciation of real exchange rate via increased competitiveness. On the other hand, with increased cost of production of domestic goods, potential output declines resulting a positive output gap, which eventually causes increased inflation. [See for example McCallum and Nelson (1999), and Allsopp et al., (2006)].

The use of General Methods of Moments (GMM) to estimate NKPC is quite common in the literature. However, in this study, GMM estimates of standard NKPC do not yield robust results and therefore not reported. Overall, the purely forward looking standard 
NKPC specification provides little evidence in explaining inflation persistence as claimed by various researchers. Rudd and Whelan (2005, p.9) reports that "[p]robably the most important implication of the NKPC model is that there is no 'intrinsic' inertia in inflation, in the sense that there is no structural dependence of inflation on its own lagged values". Therefore, in order to account for both backward and forward looking effects in inflation, hybrid NKPC is used as described in Table 4.8.

\section{(iv) Open Economy Hybrid New Keynesian Phillips Curve (NKPC)}

As discussed, price inflation process and the traditional Phillips curve (purely backward looking) show evidence of a marginal shift in inflation persistence between exchange rate regimes. However, the purely forward looking standard NKPC seems to be incapable of accounting for persistence in inflation process. In what follows, a discussion on the estimates of hybrid Phillips curve specification (equation 3.8). A summary of estimation results is shown in Table 4.9

Overall, the impact of expected inflation on current inflation varies significantly over exchange rate regimes. The parameter of interest is the coefficient on lagged inflation which accounts for inertial behaviour of inflation. As estimates in Table 4.9 suggest, inflation persistence has been around 57.03 per cent during the full sample period which is well above the estimates of purely traditional Phillips curve specification. Moreover, persistence between regimes shows a dramatic shift of about 37.67 percentage points (i.e., in the fixed regime, persistence coefficient is 26.68 per cent, while in the flexible regime it is more than double i.e., 64.35 per cent). However, it is observed that the output gap measure in the hybrid specification does not yield better results as the coefficients are in wrong signs even though they become statistically significant. Further, oil price inflation does not report significant results and the coefficient on import price inflation also shows only margina impact. However, the expected change of real exchange rate becomes highly significant in the flexible regime with an overall impact of 37.55 per cent. This can be interpreted in the same way as it is the case in estimates of standard NKPC specification. On one hand, a depreciation of real exchange rate results in an increase of output, and on the other hand, due to rise in import prices potential output declines, which eventually may give rise to a positive output gap, creating inflationary pressures on domestic consumer prices. However, in the fixed regime, none of the coefficients becomes statistically significant, which may suggest lack of expectations in real exchange rate depreciation.

In order to examine whether a shift in inflation persistence is suggestive of a structural break due to regime change, recursive estimates are carried out with respect to lagged inflation coefficient. A plot of recursive estimates is shown in Figure 4.6, which is almost identical to what is obtained in the case of price inflation process and price-based Phillips curve. There is clear evidence of a structural break in late 1970s, during the period of which

\section{Table 4.9 - Estimates of Open Economy Hybrid New Keynesian Phillips Curve}

\begin{tabular}{|c|c|c|c|c|c|c|}
\hline \multicolumn{7}{|c|}{$\begin{array}{l}\text { Dependant Variable: Consumer Price Inflation } \\
\qquad \begin{aligned} \Delta c p i_{t}=\sum_{i=1}^{4} \eta_{1} E_{t} \Delta c p i_{t-i}+\sum_{i=1}^{8} \eta_{2} \Delta g a p_{t-i}+\sum_{i=1}^{4} \eta_{3} \Delta o i l_{t-i} \\
+\sum_{i=1}^{4} \eta_{4} \Delta i m p_{t-i}+\sum_{i=1}^{4} \eta_{5}\left(\Delta \text { reer }_{t}-E_{t} \Delta r e e r_{t+i}\right)+v_{t}\end{aligned}\end{array}$} \\
\hline Independent Variable & \multicolumn{2}{|c|}{$\begin{array}{l}\text { Full } \\
\text { Sample } \\
\text { Period } \\
\text { (I) }\end{array}$} & $\begin{array}{c}\text { Fixed } \\
\text { Exchange Rate } \\
\text { Regime } \\
\text { (II) }\end{array}$ & \multicolumn{3}{|c|}{$\begin{array}{c}\text { Flexible } \\
\text { Exchange Rate } \\
\text { Regime } \\
\text { (III) } \\
\end{array}$} \\
\hline$\Delta$ cpif & $\begin{array}{l}1.2401(3) \\
(0.3647)\end{array}$ & $\begin{array}{l}-0.8001(4) \\
(0.2764)\end{array}$ & $\begin{array}{l}1.2939(1) \\
(0.2478)\end{array}$ & $\begin{array}{l}1.2192(1) \\
(0.5536)\end{array}$ & $\begin{array}{l}2.5250(3) \\
(0.6274)\end{array}$ & $\begin{array}{l}-1.83576(4) \\
(0.4573)\end{array}$ \\
\hline$\Delta \mathrm{cpi}$ & \multicolumn{2}{|c|}{$\begin{array}{l}0.5703(1) \\
(0.0858)\end{array}$} & \multicolumn{2}{|l|}{$\begin{array}{l}0.2668(1) \\
(0.1329)\end{array}$} & \multicolumn{2}{|l|}{$\begin{array}{l}0.6435(1) \\
(0.1209)\end{array}$} \\
\hline gap & $\begin{array}{c}0.5884(7) \\
(0.2894)\end{array}$ & $\begin{array}{l}-0.5072(8) \\
(0.2069)\end{array}$ & \multicolumn{2}{|l|}{$\begin{array}{l}-1.2066(7) \\
(0.6061)\end{array}$} & \multicolumn{2}{|l|}{$\begin{array}{l}-0.46624(8) \\
(0.2545)\end{array}$} \\
\hline$\Delta$ imp & \multicolumn{2}{|c|}{$\begin{array}{l}0.0957(3) \\
(0.0421)\end{array}$} & $\begin{array}{l}0.0939(3) \\
(0.0424)\end{array}$ & - & -- & -- \\
\hline$\Delta(\Delta$ reer - E $\Delta$ reer $)$ & $\begin{array}{l}0.0534(1) \\
(0.0172)\end{array}$ & $\begin{array}{l}0.0483(3) \\
(0.0193)\end{array}$ & -- & $\begin{array}{l}0.1233(1) \\
(0.0264)\end{array}$ & $\begin{array}{l}0.1041(2) \\
(0.0395)\end{array}$ & $\begin{array}{l}0.1481(3) \\
(0.0429)\end{array}$ \\
\hline \multicolumn{7}{|l|}{ No. of Observations } \\
\hline Durbin-Watson Statistic & \multicolumn{2}{|c|}{1.92} & 1.88 & \multicolumn{3}{|c|}{1.90} \\
\hline Serial Correlation (LM Te & \multicolumn{2}{|c|}{0.60} & 0.63 & \multicolumn{3}{|c|}{0.88} \\
\hline R-Squared & \multicolumn{2}{|c|}{0.43} & 0.77 & \multicolumn{3}{|c|}{0.51} \\
\hline
\end{tabular}

Notes:

1. Asymptotic standard errors are in parentheses below the estimated coefficients. Four leads of expected inflation and four lags of every other variables (except for output gap with eight lags) are used as instruments. Only the statistically significant lags are reported. The lag/lead number is indicated besides the coefficient estimate. 2. LM test reports the probability value for rejecting the null hypothesis of no serial correlation.

economic liberalization policies were introduced, and also the exchange rate regime change occurred.

However, in order to identify shift in inflation persistence coincides with the regime change, Chow breakpoint tests are carried out as before. Chow test assumes parameter stability between two regimes, i.e., the estimates in columns II and III in Table 4.9 are statistically the same. Results are summarised in Table 4.10. Both the $F$-statistic and the log Likelihood ratio provide strong evidence of parameter instability between regimes, rejecting the null hypothesis of no structural break at 1 per cent level for all the breakpoints considered. Further, evidence of a structural break becomes more apparent even after two years of the 
Figure 4.6 - Recursive Estimates of Lagged Pricelnflaction Coefficient of Open Economy Hybrid NKPC

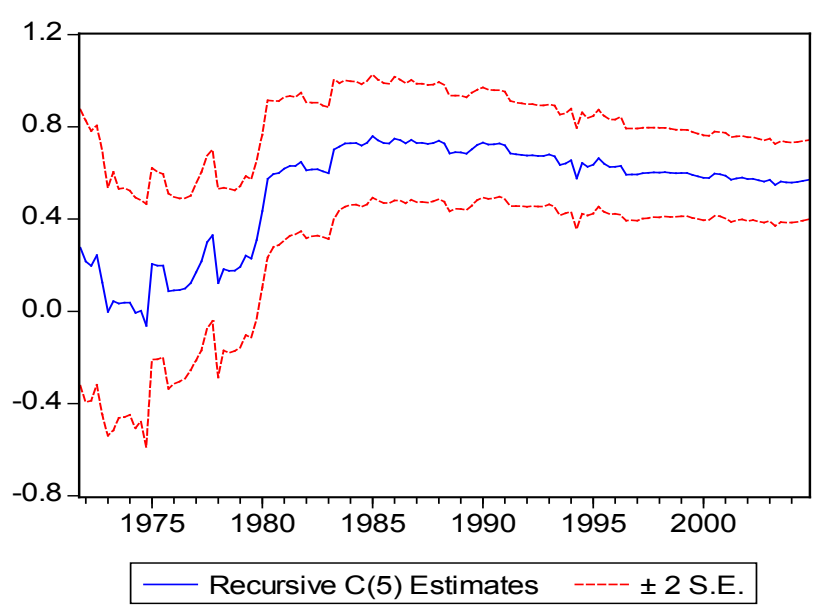

Table 4.10 - Estimates of Chow Breakpoint Tests of Hybrid NKPC

\begin{tabular}{lcccc}
\hline & \multicolumn{4}{c}{ Breakpoints } \\
\cline { 2 - 5 } & $\mathbf{1 9 7 7 Q 4}$ & $\mathbf{1 9 7 8 Q 1}$ & $\mathbf{1 9 7 9 Q 1}$ & 1980Q1 \\
\hline F-statistic & 1.8845 & 2.0889 & 2.0907 & 1.9211 \\
& $(0.0104)$ & $(0.0034)$ & $(0.0034)$ & $(0.0086)$ \\
Log likelihood ratio & 64.4876 & 70.2215 & 70.2729 & 65.5299 \\
& $(0.0001)$ & $(0.0000)$ & $(0.0000)$ & $(0.0000)$ \\
\hline
\end{tabular}

Note: The probability values are presented in parenthesis below the computed test statistics.

regime change, suggesting gradual adjustment process of expectations subsequent to the policy changes.

Overall, inflation persistence as measured by type I definition, seems to have been highly persistent in the flexible regime than in the fixed regime, as evidenced by estimates of price inflation process, price based Phillips curve and the hybrid Phillips curve. Further, as shown in recursive estimates and Chow tests for the hybrid NKPC specification, there is strong evidence of parameter instability before and after the exchange rate regime change.

\section{Estimation of Type II Inflation Persistence}

Type II inflation persistence refers to systematic component of monetary policy actions and is measured by lags between the change in monetary policy measures and the peak effects of inflation. As described in the previous section, price inflation process indicates a slight shift in persistence parameters with the regime change, and the hybrid NKPC estimates provide strong evidence in support of a dramatic upward shift of inflation persistence between regimes. One of the major conclusions of AS (1991) is that "the persistence of inflation is a positive function of the degree of monetary and exchange rate accommodation" (p.1272). Accordingly, they show that the higher monetary accommodation of inflation, in the flexible regime, leads to increased inflation persistence. However, this proposition is challenged by recent studies. For example, Bleaney (2001) argues that "[t]here is no presumption, that monetary policy will necessarily be more accommodating under floating rate" (p.396). Therefore, the aim of this section is to empirically test these contrasting views. First, the correlation tests are carried out in order to gauge any relations between change in monetary policy measures and inflation. Second, the degree of monetary accommodation is examined during the fixed and flexible regimes, separately.

\section{(i) Correlations between Monetary Policy Measures and CPI Inflation}

In Sri Lanka, monetary policy operates through a monetary targeting framework. Major monetary policy tools used are (active) Open Market Operations (OMO), Statutory Reserve Requirement (SRR) and the Bank Rate (the lending rate to commercial banks by CBSL). The annual report for published by the Central Bank for 2005 states that "[ $t$ ]he Central Bank conducted monetary policy operations within the monetary targeting framework, under an independent floating exchange rate system" (CBSL Annual Report, 2005, p.114). Accordingly, CBSL currently adopts the Reserve Money (high powered money) as the operating target while a broad money measure $\left(\mathrm{M}_{2 \mathrm{~b}}\right)^{6}$ as the intermediate target. However, the use of $\mathrm{M}_{2 \mathrm{~b}}$ as a policy measure is a recent development aimed at taking account of the impact of Foreign Currency Banking Units (FCBUs), on the domestic economy. Historically, CBSL has used narrow money $\left(\mathrm{M}_{1}\right)$ as the policy measure followed by broad money $\left(\mathrm{M}_{2}\right)$ in the 1980s, with the rapid expansion of economic activities. Therefore, this study will use all three measures of money supply and short term real interest rate in order to examine type II inflation persistence. A review of previous work on measuring type II inflation persistence provides no evidence of a commonly agreed measure to estimate inflation persistence and also there is no appropriate statistic (Batini, 2002). Therefore, examining with several policy measures would provide fuller description of data and strengthen the analysis. Results, thus obtained, are summarised in Table 4.11 .

6/ The consolidated broad money $\left(\mathrm{M}_{2 \mathrm{~b}}\right)$ includes broad money plus the operations of foreign currency banking units (FCBUs). 
Table 4.11 - Correlations between CPI Inflation and Monetary Policy Measures

\begin{tabular}{|c|c|c|c|c|}
\hline \multirow{3}{*}{ Period } & \multicolumn{4}{|c|}{ Monetary Policy Measure } \\
\hline & \multicolumn{3}{|c|}{ Money Growth } & \multirow{2}{*}{$\begin{array}{l}\text { Change in Short term } \\
\text { Real Interest Rate }\end{array}$} \\
\hline & $M_{1}$ & $M_{2}$ & Reserve Money & \\
\hline $\begin{array}{l}\text { Full Sample } \\
\text { (1960Q1- 2005Q4) }\end{array}$ & $0.1551(7)$ & $0.2248(14)$ & $0.1943(10)$ & $-0.1613(4)$ \\
\hline $\begin{array}{l}\text { Fixed Exchange Rate Regime } \\
(1960 \mathrm{Q} 1-1977 \mathrm{Q} 3)\end{array}$ & $0.1285(7)$ & $0.2046(4)$ & $0.2210(9)$ & $-0.2048(1)$ \\
\hline $\begin{array}{l}\text { Flexible Exchange Rate Regime } \\
(1977 \text { Q4 - 2005Q4) }\end{array}$ & $0.3612(11)$ & $0.2946(14)$ & $0.2661(10)$ & $-0.1936(4)$ \\
\hline
\end{tabular}

Notes: Maximum values of the correlation estimates are reported with number of leads (in quarters) in parentheses.

As Table 4.11 shows, correlation estimates of all monetary policy measures over CPI inflation are significantly smaller through out the sample period. This suggests a modest relation between money and inflation during the period under study. However, when considered the estimates separately across regimes, coefficients are slightly higher in the flexible regime. Overall, the number of lags between the change in monetary aggregates and the peak effects of inflation is found to be larger in the flexible exchange rate regime than in the fixed regime, which in turn implies higher persistence.

During the fixed regime, inflation responds fairly quickly to $\mathrm{M}_{2}$ and it reaches maximum after four quarters of change in $\mathrm{M}_{2}$, suggesting lower persistence. However, response of inflation to $\mathrm{M}_{1}$ and Reserve Money takes comparatively longer lags. On the other hand, response of inflation to real interest rate seems fairly quicker during the fixed regime. A possible reasoning for this response is, perhaps, the use of more direct controls by the Central Bank to curtail inflation during that period. However, estimates of interest rate as a monetary policy tool does not seem to yield significant results during the fixed regime period. However, during that period Bank Rate has been more prominent as a policy rule.

By contrast, during flexible regime, peak response of inflation to $M_{2}$ records after fourteen quarters which indicates higher inflation persistence. The maximum response of inflation to changes in $\mathrm{M}_{1}$ and Reserve Money takes eleven and ten quarters, respectively. Further, response of inflation to real interest rate shows four quarter lag in the flexible regime, however the correlation is comparatively low. The weak correlation between interest rate and consumer price inflation in Sri Lanka may, perhaps, be due to under-developed financia sector and inefficiency in banking sector, the points highlighted in previous country studies, Thenuwara (1998).

Overall, results suggest that the lag between monetary policy actions and inflation has widened dramatically before and after the regime change. Several researchers attempt to measure the relationship between money growth and inflation using data for developed countries. Batini and Nelson (2001) use monthly data for U.S. and U.K. for the period February 1953 to August 2001. They show that the lead of money over inflation ranging from 12 to 49 months (i.e., nearly 4 to 16 quarters) for U.S. and that of U.K. is 6 to 24 months (i.e., nearly 2 to 8 quarters). But they do not relate these difference estimates with the changes of policy regimes. Similarly, Batini (2002) uses quarterly data to model inflation persistence in the Euro area and estimates a lead of money growth over inflation ranging from 2 to 16 quarters for the period 1970Q1 to 2000Q4. Both studies find significant correlations between monetary policy measures and consumer inflation. ${ }^{7}$ However, their results are not directly comparable with the findings of the present study, due to differences in country sample.

\section{(ii) Estimates of Degree of Monetary Accommodation}

In order to examine type II inflation persistence further, the monetary accommodation parameters are examined, as suggested by AS (1991). AS show that changes in international monetary and exchange rate regimes were associated with corresponding changes in monetary accommodation. Accordingly, they examine the degree of monetary accommodation assuming exogenous component of money supply rule is a random walk with a drift (p.1269).

The process of monetary accommodation is a simple monetary policy reaction function which describes the central bank behaviour in response to changes in price level as a feedback rule. The coefficient on lagged inflation term measures the degree of monetary accommodation, where setting it equal to zero means no monetary intervention by the central bank (i.e., the case of independent float), while it is being equal to unity means perfect monetary accommodation, where price shocks are completely offset by changes in money supply (Akiba, 2002). Further, more than unity coefficient value implies that rise in price level leads to under proportionate adjustment in nominal money supply while less than unity coefficient relates to over proportionate adjustment. The former case leads to decrease in real money balances while latter leads to an increase of real balances. If the monetary accommodation coefficient takes a negative value, central bank reacts to an increase in price level by reducing the nominal money supply. Accordingly, tests of monetary accommodation coefficients across the regimes are conducted using equation 3.10. However, more lags need to be allowed in instrumental variables than in the original specification, as shown in Table 4.12 and Table 4.13 for the fixed and flexible regimes, respectively.

Initially, the regression was specified with four dependent variables, namely, lagged terms of consumer inflation, short term interest rate, real GDP growth and lagged terms of the dependent variable. However, last two variables do not yield significant results at conventional significance levels, therefore the coefficients are not reported.

$7 /$ Batini and Nelson (2001) adopt adjusted money base, $\mathrm{M}_{2}$ and change in short real rate as monetary policy measures while Batinil(2002) uses $\mathrm{M}_{3}$ and short real rate. 


\section{Table 4.12 - Estimates of Monetary Accommodation Coefficients in Fixed Exchange Rate Regime}

\section{Dependent Variable : Growth in Money Supply}

$$
\Delta m_{t}=\gamma_{0}+\sum_{i=1}^{12} \gamma_{1} \Delta c p i_{t-i}+\sum_{i=1}^{8} \gamma_{2} \Delta i r_{t-i}+\sum_{i=1}^{8} \gamma_{3} \Delta g a p_{t-i}+\sum_{i=1}^{12} \gamma_{4} \Delta m_{t-i}+\mu_{t}
$$

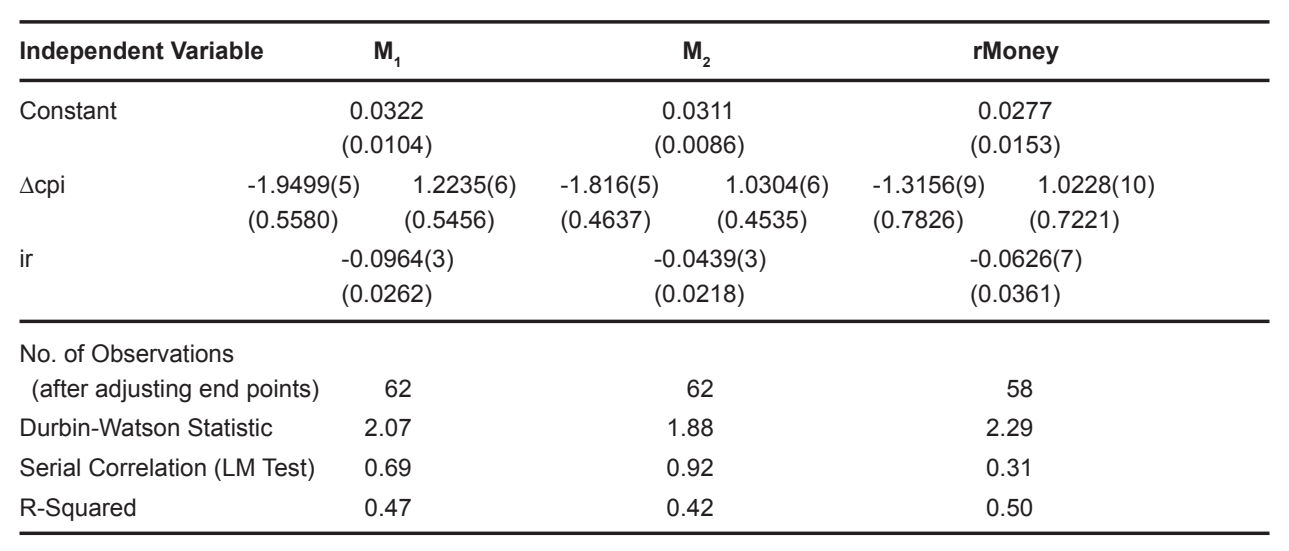

\section{Notes:}

1. Asymptotic standard errors are in parentheses below the estimated coefficients. Only the statistically significant lags are reported. The lag number is indicated in parentheses besides the coefficient estimate. The lagged values of dependent variable and the GDP are found to be insignificant in standard significance levels.

2. LM test reports the probability value for rejecting the null hypothesis of no serial correlation

As shown, coefficients on $M_{1}$ and $M_{2}$ are significant in fifth and sixth lags at 5 per cent significance level. Overall, the impact of monetary growth in response to changes in inflation has been negative, where, the sum of coefficients is about -0.75 per cent in both $M_{1}$ and $M_{2}$ estimates. This indicates that during the fixed regime, monetary policy is shaped by stringent policy stance, where no monetary accommodation of inflation differentials. Moreover, the coefficient on response of Reserve Money is also negative. It is important to note that most of the previous studies focus on the experience in developed countries and therefore their conclusions may not be directly comparable with the findings of the present study.

In addition to the degree of monetary accommodation, coefficients on lagged interest rate terms provide evidence on the slower adjustment of nominal money supply to changes in the interest rates. As shown in Table 4.12, the changes in interest rates affect nominal money supply growth with a three quarter lag in case of both $\mathrm{M}_{1}$ and $\mathrm{M}_{2}$, and with seven quarters in Reserve Money. However, the coefficient estimates are smaller in magnitude.

\section{Table 4.13 - Estimates of Monetary Accommodation Coefficients in Flexible Exchange Rate Regime}

\section{Dependent Variable : Growth in Money Supply}

$$
\Delta m_{t}=\gamma_{0}+\sum_{i=1}^{12} \gamma_{1} \Delta c p i_{t-i}+\sum_{i=1}^{8} \gamma_{2} \Delta i r_{t-i}+\sum_{i=1}^{8} \gamma_{3} \Delta g a p_{t-i}+\sum_{i=1}^{12} \gamma_{4} \Delta m_{t-i}+\mu_{t}
$$

\begin{tabular}{lccc}
\hline Independent Variable & $\mathbf{M}_{\mathbf{1}}$ & $\mathbf{M}_{\mathbf{2}}$ & rMoney \\
\hline Constant & 0.0242 & 0.0127 & 0.0006 \\
& $(0.0152)$ & $(0.0120)$ & $(0.0147)$ \\
$\Delta \mathrm{cpi}$ & - & $0.3294(4)$ & $0.4476(12)$ \\
& & $(0.1774)$ & $(0.2419)$ \\
ir & $-0.0047(4)$ & $-0.0044(4)$ & $-0.0047(8)$ \\
& $(0.0019)$ & $(0.0015)$ & $(0.0020)$ \\
$\Delta$ Lagged Dependant Variable & $0.3206(4)$ & $0.3411(4)$ & $0.2472(3)$ \\
& $(0.1074)$ & $(0.1058)$ & $(0.0991)$ \\
\hline No. of Observations (after adjusting end points) & 112 & 112 & 112 \\
Durbin-Watson Statistic & 1.98 & 1.97 & 1.98 \\
Serial Correlation (LM Test) & 0.32 & 0.54 & 0.71 \\
R-Squared & 0.40 & 0.42 & 0.39 \\
\hline
\end{tabular}

\section{Notes:}

1. Asymptotic standard errors are in parentheses below the estimated coefficients. Only the statistically significant lags are reported. The lag number is indicated in parentheses besides the coefficient estimate. The coefficients of lagged GDP terms as an explanatory variable are found to be insignificant at conventional significance levels.

2. LM test reports the probability value for rejecting the null hypothesis of no serial correlation

As shown in Table 4.13, results in the flexible regime are mixed. Coefficients on lagged inflation terms in the regression for $\mathrm{M}_{1}$ are found to be insignificant. However, significan coefficients are obtained when more lags are added (e.g.: lag 15), however, with wrong sign. In contrast, estimates of lagged $\mathrm{M}_{2}$ and Reserve Money terms become significant in fourth lag for $\mathrm{M}_{2}$ and twelfth lag for Reserve Money. Both coefficients suggest only lower degree of accommodation in the flexible regime which indicates an over proportionate adjustment of nominal money supply in response to inflation. Among the monetary policy measures considered, $\mathrm{M}_{2}$ shows comparatively quicker adjustment in response to inflation which is approximately within an year, while Reserve Money, in contrast, takes almost three years.

As shown in Table 4.13, effects of interest rate changes on money growth have been marginal during the flexible regime. Coefficients on lagged interest rate terms are in the expected sign, but very smaller in magnitude. This suggests that during the flexible regime, adjustment of nominal money for changes in interest rates shows only moderate relationship. Overall, results suggest that during the flexible regime, there is some evidence on more monetary accommodation compared to fixed exchange rate regime which results in higher inflation persistence. There is no evidence on monetary accommodation during the fixed 
regime, while the monetary policy has been most relying on direct controls. Among the alternative policy measures, $M_{2}$ seems to generate better results, however, the effectiveness of $\mathrm{M}_{2}$ as a monetary policy measure has not been significant during the flexible regime.

\section{E. Estimates of Type III Inflation Persistence}

As described, type III inflation persistence relates to lagged response of inflation to policy shocks (non-systematic policy actions). In order to identify the behaviour of lagged inflation on policy shocks, the VAR system is estimated over two regimes. Then, the impulse response functions are obtained on innovations to different monetary policy measures namely, short term interest rate and growth in monetary aggregates i.e., $\mathrm{M}_{1}, \mathrm{M}_{2}$ and Reserve Money. The impulse response functions are used to examine the number of lags of peak inflation response to policy shocks.

In specifying VAR, ordering of variables is important. The ordering used in this study is: output, inflation, real exchange rate and interest rate, which is in line with previous research [see for example Bernanke and Blinder (1992), Bernanke and Mihov (1998)]. This implies that policy shocks have no contemporaneous impact on output. However, this assumption heavily relies on frequency of data, i.e., the more frequency of data, the better would be the plausibility of the assumption. Apparently, quarterly data seem to be more plausible when compared to annual data, given monthly data would be more appropriate, but not available for all series for the entire sample period). Further, in order to avoid a potential problem of VAR estimates i.e., the price puzzle (a positive shock to interest rate tends to be followed by a rise in the price level), oil price index is included as an exogenous variable in the VAR system. Inclusion of inflation-sensitive prices such as oil and commodity prices in the VAR system is regarded as the most apparent remedy for the price puzzle.

\section{Figure 4.7 - Stability of the VAR System}

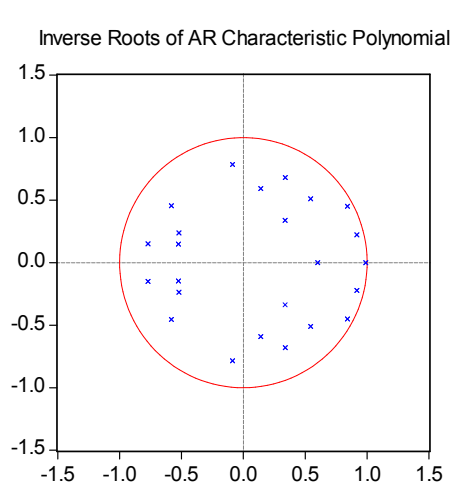

(a) Fixed Exchange Rate Regime

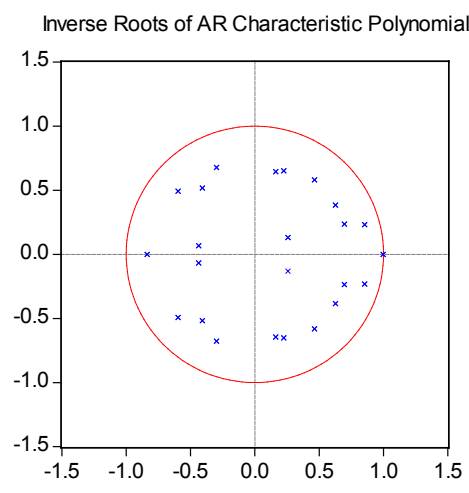

(b) Flexible Exchange Rate Regime
Before estimating the VAR system as specified in equation 3.11, its stability is verified using inverse roots of the characteristic polynomial. As shown in Figure 4.7, all roots lie inside the unit circle for both cases of fixed and flexible exchange rate regimes.

Further, the VAR system is estimated using four lags as suggested by VAR lag order selection criteria. Both Akaike Information Criterion (AIC) and 'sequential modified LR test statistic' (each test at 5 per cent level) suggest four lag structure as the optimal for the system. Estimates are obtained for the two regimes separately. Based on VAR estimates, impulse response functions are obtained for shocks on monetary policy measures with 'analytic (asymptotic)' standard errors. The responses include two standard error bands with Choleski one standard deviation (SD) innovations. All impulse responses are obtained for a period of 20 quarters. The main interest lies on the impulse response functions of CPI inflation caused by innovations to monetary policy measures. Results are presented in Figures from 4.8 to 4.11 for each monetary policy measure, separately. Each figure includes analysis for both fixed and flexible regime.

Figure 4.8 shows response of inflation to shocks on interest rates, for the two regimes, separately. In the fixed regime [Panel $(a)$ ], the peak effect of inflation marks at lag five and the total effect of the shock dies out after about ten lags. However, it is noted that during the fixed regime the Central Bank extensively used the Bank Rate and some direct measures like credit controls. The Bank Rate which proxies for the policy interest rate during the fixed

\section{Figure 4.8 - Impulse Response Functions caused by Innovations to Interest Rate}
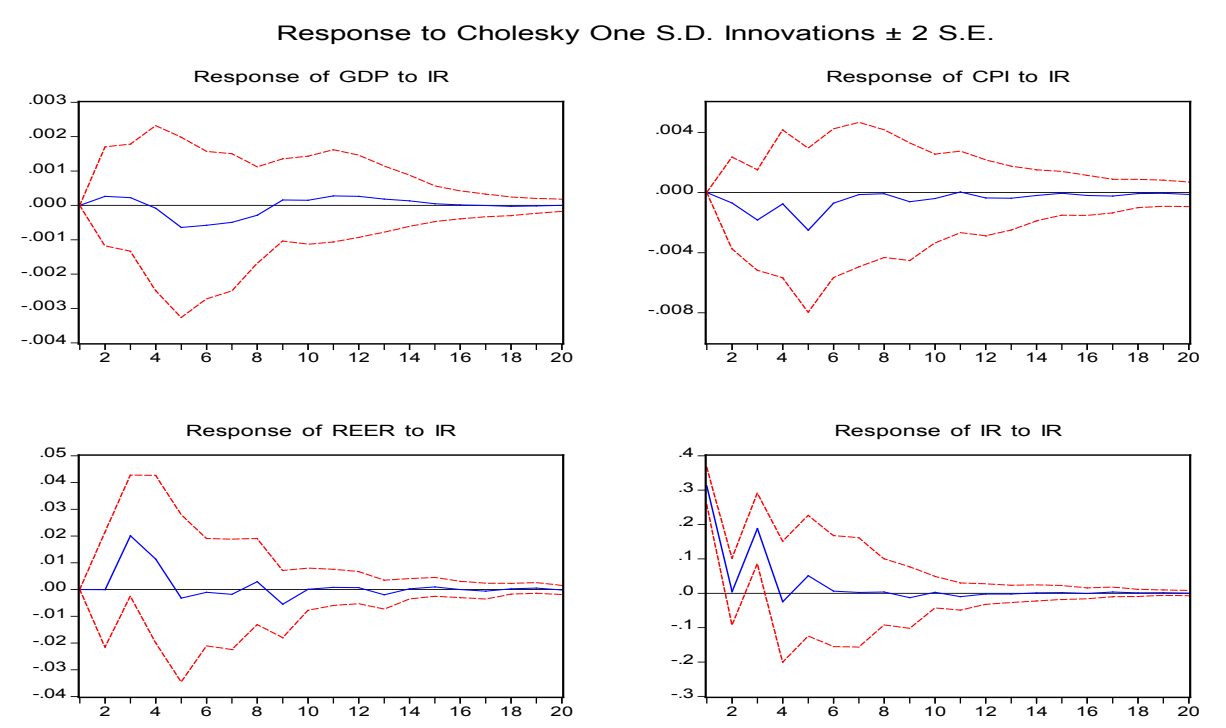

(a) Fixed Exchange Rate Regime 

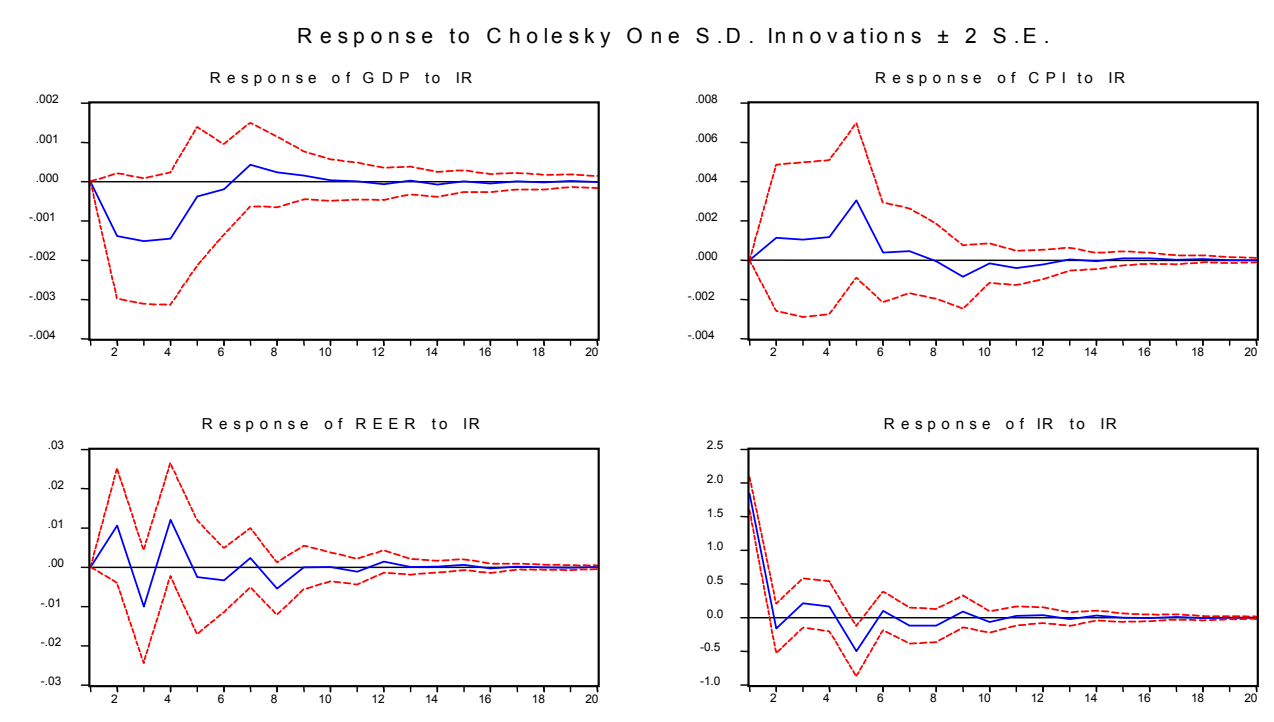

(b) Flexible Exchange Rate Regime

regime has been fixed for several years i.e., it has been changed only four times during that period which spans from 1960Q1 to 1977Q3. Therefore, during the fixed regime, the impulse responses of inflation to interest rate shocks do not yield robust results (this problem can be overcome with use of other monetary policy measures as described below).

However, the policy interest rate during the flexible regime is proxied by short term Treasury Bill rate. Results are presented in Panel $(b)$ of Figure 4.8. As shown in the upperright corner, results do not suggest evidence on inflation persistence due to emerge of the price puzzle. This suggests that the inclusion oil price inflation is not fully capable of eliminating the price puzzle. Various interpretations have been put forwarded by researchers in explaining the price puzzle. Walsh (2003) describes that " $[t]$ he most commonly accepted explanation for the price puzzle is that it reflects the fact that the variables included in the VAR do not span the full information set available to the [monetary authority]." However, some researchers argue that the price puzzle is not an outcome of misspecification of the VAR system, but due to some other aspects like cost channel of monetary policy [Barth and Ramey, 2001 (quoted Walsh, 2003, p.29)].

Due to these drawbacks in using the interest rate to account for policy shocks, the use of monetary aggregates may seem to be more plausible. As described before, correlation estimates between inflation and money growth show significant differences before and after the regime change. In the flexible regime, peak response of inflation to monetary policy changes takes longer lags than in the fixed regime. This initial finding is further strengthened by inflation response to impulses on monetary measures.
Figure 4.9 - Impulse Response Functions caused by Innovations to $\mathrm{M}_{1}$

Response to Cholesky One S.D. Innovations \pm 2 S.E.
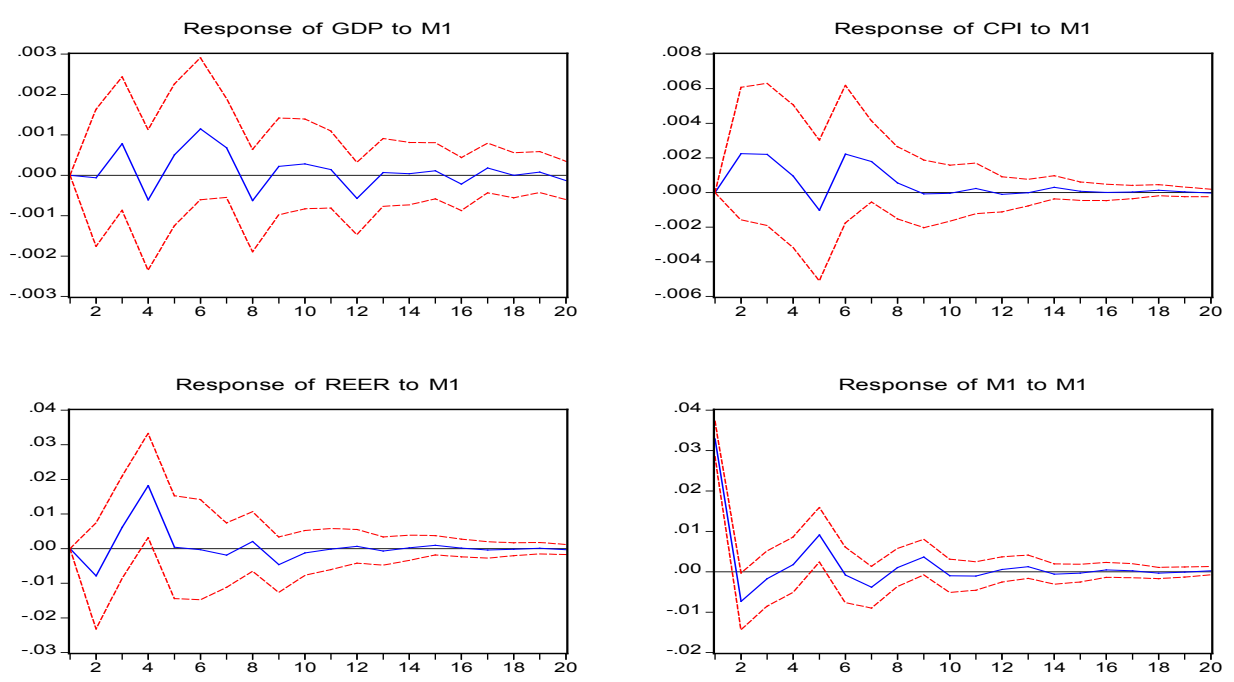

(a) Fixed Exchange Rate Regime

Response to Cholesky One S.D. Innovations \pm 2 S.E.
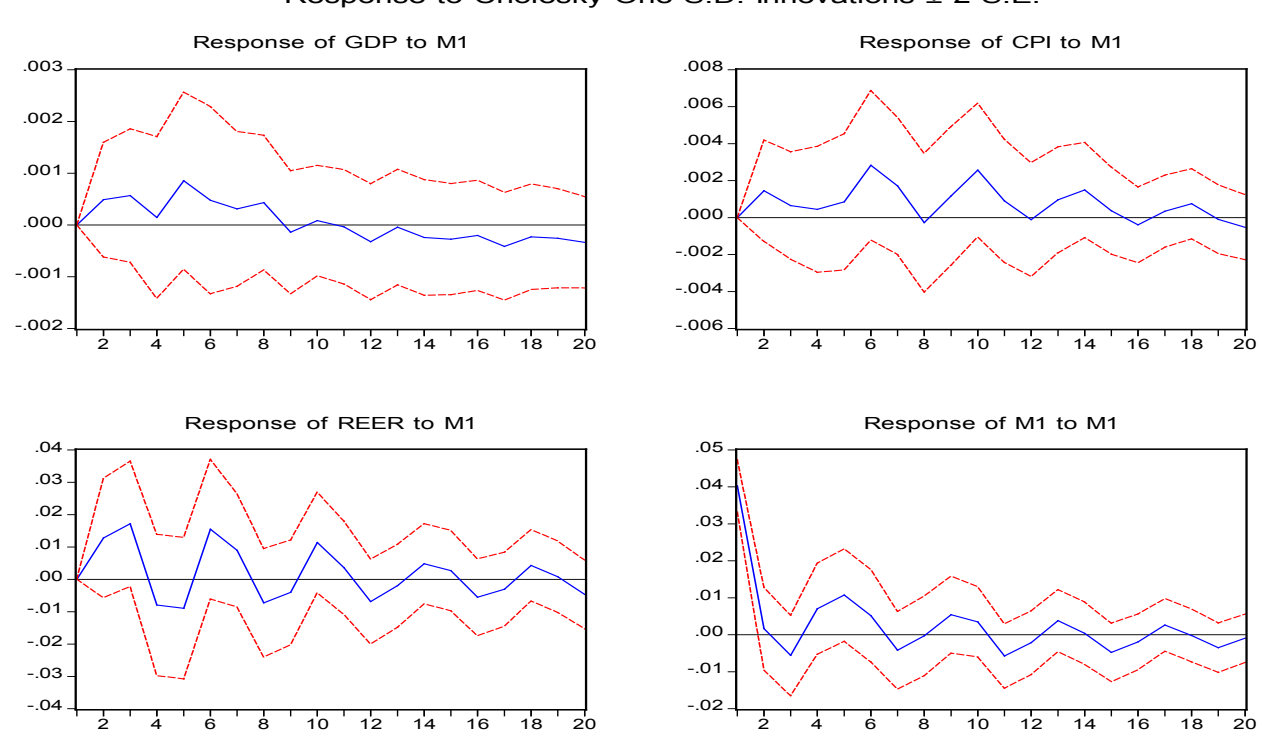

(b) Flexible Exchange Rate Regime 


\section{Figure 4.10 - Impulse Response Functions caused by Innovations to $M_{2}$}

Response to Cholesky One S.D. Innovations \pm 2 S.E.
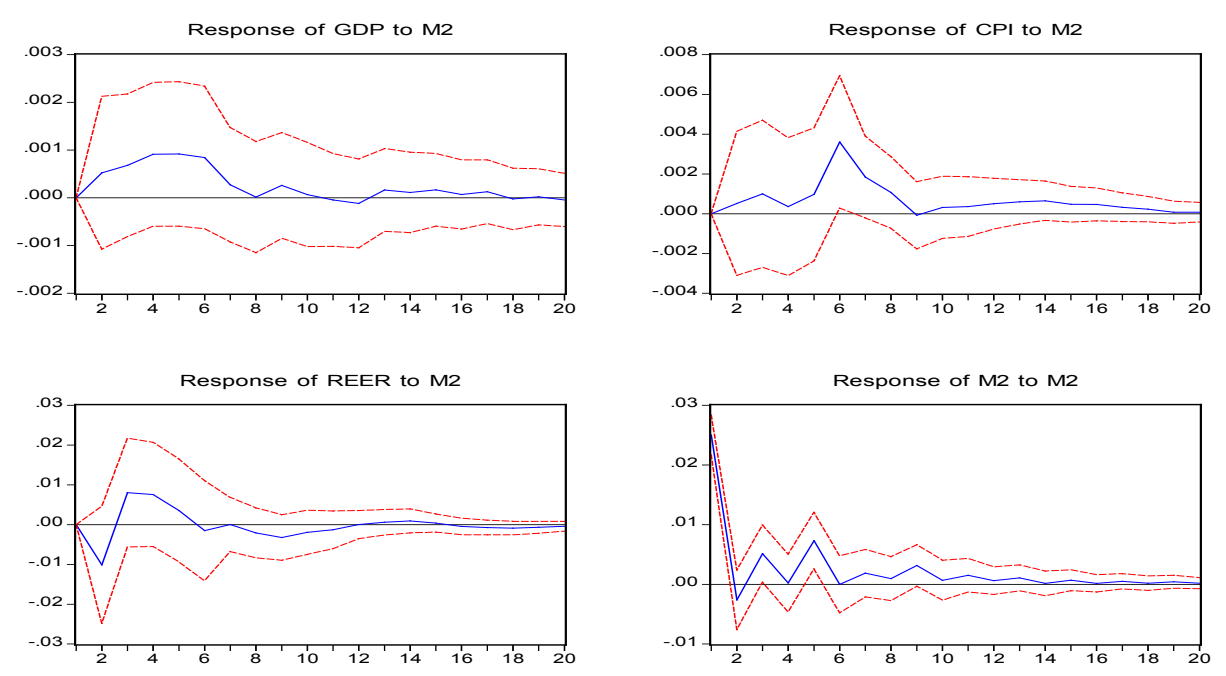

(a) Fixed Exchange Rate Regime

Response to Cholesky One S.D. Innovations \pm 2 S.E.
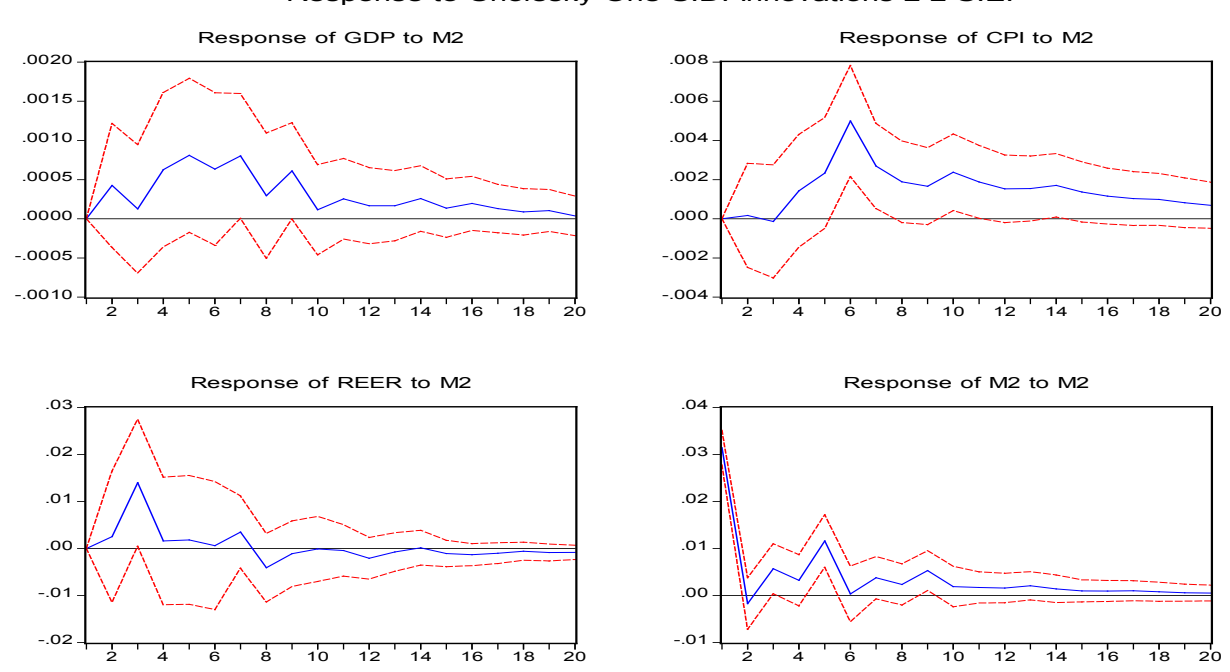

(b) Flexible Exchange Rate Regime
Figure 4.11 - Impulse Response Functions caused by Innovations to Reserve Money

Response to Cholesky One S.D. Innovations \pm 2 S.E.
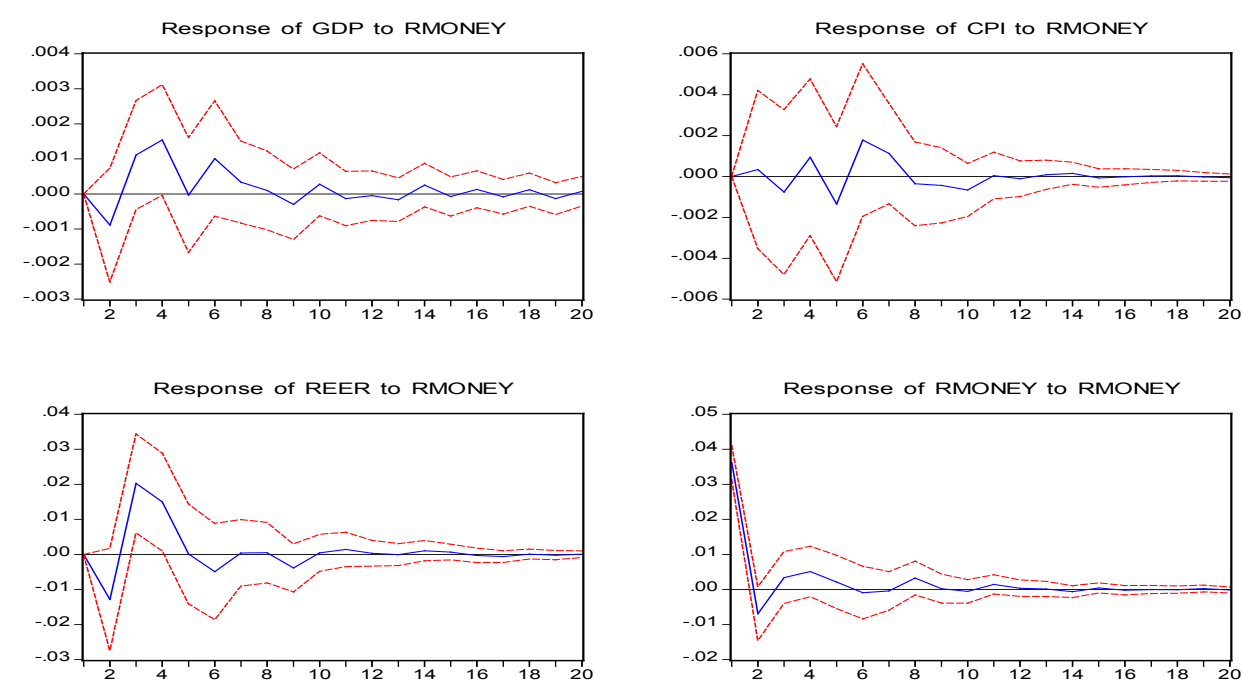

(a) Fixed Exchange Rate Regime

Response to Cholesky One S.D. Innovations \pm 2 S.E.
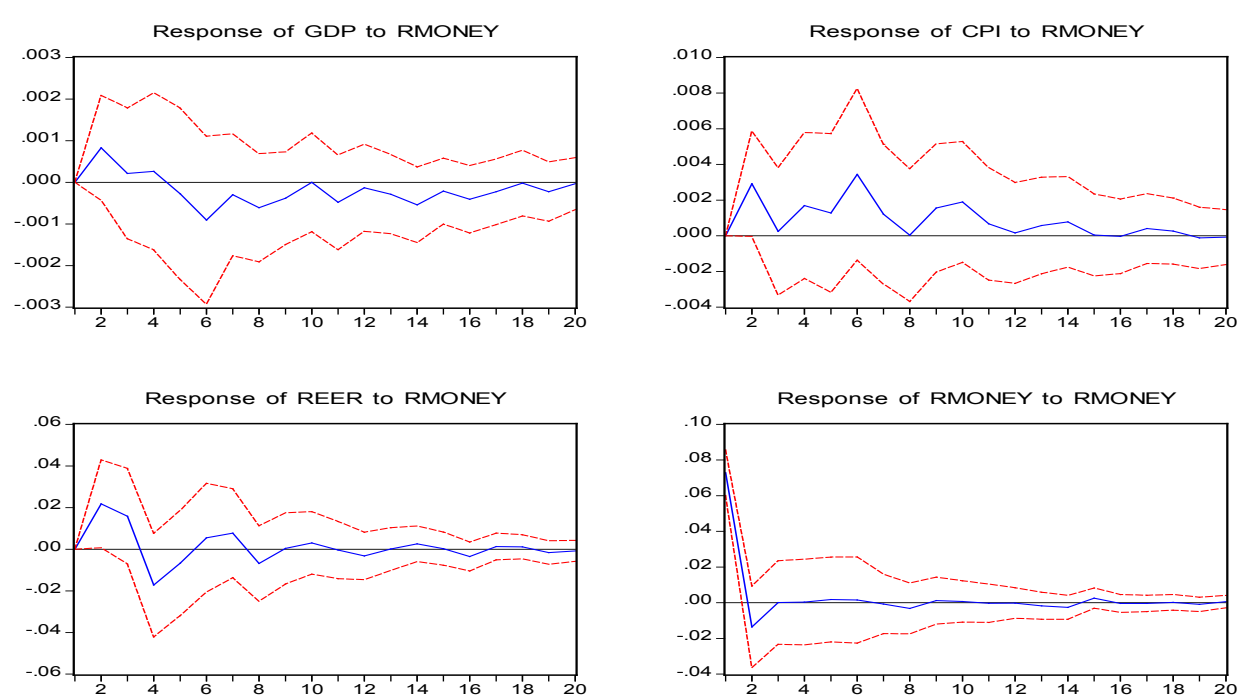

(b) Flexible Exchange Rate Regime 
The response of inflation to shocks on $\mathrm{M}_{1}, \mathrm{M}_{2}$, and Reserve Money are shown in Figures $4.9,4.10$ and 4.11, respectively. Results show that the effects of a policy shock are more persistent during the flexible regime, than in the fixed regime. However, time taken for peak inflation response followed by policy shock is not significantly different between regimes. Therefore, results of the impulse response analysis are mixed. Figure 4.9 shows that in the fixed regime, total effect of a shock to $M_{1}$ disappears after about eight lags with the peak effect reporting after six lags. In contrast, during the flexible regime the shock persists for longer, reporting the peak effect after ten quarters.

Similarly, Figure 4.10 shows the lagged inflation response to shocks on $\mathrm{M}_{2}$. In the fixed regime $[$ Panel $(a)]$, effects of the shocks are transitory and mark the peak after six quarters. In contrast, during the flexible regime, shocks to $\mathrm{M}_{2}$ seems long lived though the peak effect points at lag six as same as in the fixed regime.

Identical results are observed when Reserve Money is used as the monetary policy measure, as depicted in Figure 4.11. Inflation records the peak effect followed by a shock to Reserve Money after about six lags in both regimes. However, the persistence of the shock is long lasting in the flexible regime. Overall, results suggest that the effects of a shock to monetary policy measures during the flexible regime take a longer time to completely die out, than in the fixed regime. This implies that during the flexible exchange rate regime inflation appears to be more persistent than in the fixed regime.

\section{Conclusion}

This paper examines inflation performance in Sri Lanka across different exchange rate regimes. The degree of inflation persistence is used as a proxy for examining inflation performance. Sample period spans from 1960Q1 to 2005Q4, and exchange rate regimes are categorised under broader classification, namely, fixed exchange rate regime (pre 1977Q4 period) and flexible exchange rate regime (post 1977Q4 period).

The study is carried out with respect to three objectives. First, evidence on the degree of inflation persistence is examined through price inflation process and three Phillips curve specifications, namely, price-based traditional Phillips curve (purely backward-looking), standard NKPC (purely forward-looking) and hybrid-NKPC (incorporating both forward and backward-looking elements). Second, inflation response to systematic monetary policy actions is examined through correlation between money growth and inflation. Finally, an unrestricted VAR system identifies the inflation response to non-systematic policy shocks, through impulse response functions.

The study examines three definitions (types) of inflation persistence followed by Batini and Nelson (2001). Type I inflation persistence relates to positive serial correlation in inflation, while type II relates to the number of lags between (systematic) monetary policy actions and the peak effect of inflation. Type III inflation persistence relates to the lagged response of inflation to policy shocks i.e., non-systematic policy actions. Major findings and conclusions of the study are described below.

First, Type I inflation persistence is examined through consumer price inflation process and Phillips curve specifications. The coefficient on lagged inflation in price inflation process provides some evidence on an upward shift in inflation persistence between regimes, which is consistent with AS's (1991) findings. Recursive estimates also suggest a shift in inflation persistence during the period of regime change. These results are further confirmed by Chow parameter stability tests. Among the open economy Phillips curve specifications examined, price-based Phillips curve suggests a modest shift in inflation persistence providing evidence on parameter instability between regimes. However, estimates of the purely forward-looking NKPC seem to be incapable of accounting for inflation persistence, as claimed by many researchers [see for example Rudd and Whelan (2005)]. According to the estimates of the hybrid NKPC, inflation persistence records a dramatic upward shift between regimes. Recursive estimates and parameter stability tests re-confirm these results. Further, parameter stability tests provide significant evidence even after one year of the regime change, which may, perhaps, be due to accumulated effects of various policy measures being implemented during that period. It also implies that the slower adjustment process of inflation expectations, followed by the policy change.

Second, estimates of Type II inflation persistence suggest that there is a significant lag between the peak effect of inflation followed by a change in the monetary policy measures. Results show that during the flexible regime, inflation has been more persistent than in the fixed regime. However, correlation between money and inflation seems to be modest through out the sample period. Further, the estimates of degree of monetary accommodation yield negative coefficients during the fixed regime providing no evidence of accommodation, while in the flexible regime there is significant evidence of monetary accommodation, which results in higher inflation persistence.

Type III inflation persistence is examined through impulse response functions caused by innovations to monetary aggregates and short term interest rate. In the fixed regime, effects of a policy shock seem to be less persistent compared to flexible regime. However, inflation response to changes in interest rate provides only weak evidence due to emerge of price puzzle. Overall, impulse response analysis provides mixed evidence on inflation persistence across regimes.

The findings of this study may have important implications on the assessment and design of monetary policy framework in Sri Lanka. Since the abandonment of fixed exchange rate regime, coupled with open economic policies, inflation persistence reaches a higher level, perhaps, with increased monetary accommodation. In contrast, before the regime change, inflation shows lower persistence and lower monetary accommodation. Nonetheless, these 
findings may not suggest that the pegged exchange rate system to be restored. Instead, it may highlight the importance of precommitment to policy measures that is necessary to curtail inflationary pressure. Further, in order to maintain inflation persistence at a lower level, several other factors need to be considered, such as maintaining consistency between policy objectives and policy instruments, time consistency of policy announcements etc.

However, this study has several limitations, some of which are related to data availability. Mainly, a proper 'policy' interest rate series does not exist for the entire sample period. Further, data on consolidated broad money $\left(\mathrm{M}_{2 \mathrm{~b}}\right)$, which is the intermediate target of the present monetary targeting framework, is available only for the recent ten years. The effects of oil price inflation on domestic consumer prices seem to have not captured well due to apparent deficiencies in the consumer price index, because of administered prices. Further, there are some limitations due to policy implications. It is a fact that in developing countries like Sri Lanka, fiscal concerns may influence on monetary policy effectiveness. Therefore, taking account of the effects of macroeconomic policies may improve the results. Expanding the analysis by including more variables such as external debt, official foreign reserves, domestic credit expansion, government spending etc. may lead to more robust results Further, one may consider the independently floating exchange rate system as a separate regime, as when the present study is carried out, the period of independent floating is too short to be considered as a credible regime.

Moreover, in this paper more emphasis is placed on persistence in inflation under different exchange rate regimes. However, it can be extended to account for the effects of exchange rate shocks and costs of exchange rate fluctuations within and between exchange rate regimes. Also the exchange rate pass-though effects in different exchange rate regimes is yet to be considered. Overall, more research may be needed on the effects of exchange rate variability and monetary policy models that fully endogenise exchange rate effects.

\section{References}

Agenor, P. R., (2004), “The Economic of Adjustment and Growth”, Second Edition, Harvard University Press.

, and Taylor, M. P., (1992), "Testing for Credibility Effects", IMF Staff Papers, International Monetary Funds, Vol. 39(3), pp.545-571.

Akiba, H., (2002), "Monetary Reactions, Alternative Expectations, and Exchange rate Dynamics", Waseda University, Japan, mimeo.

Allsopp, C., Kara, A. and Nelson, E., (2006), “U.K. Inflation Targeting and The Exchange Rate”, Working Papers Series, 2006-030A, Federal Reserve Bank of St. Luis.

Alogoskoufis, G, (1992), "Monetary Accommodation, Exchange Rate Regimes and Inflation Persistence", Economic Journal: The Journal of Royal Economic Society, Vol. 102 (May), pp.461-80

Alogoskoufis, G. and Smith, R. P., (1991), "The Phillips Curve, the Persistence of Inflation, and the Lucas Critique: Evidence from Exchange Rate Regimes", American Economic Review, Vol. 81 (December), pp.1254-75.

Ball, L., (1999), "Efficient Rules for Monetary Policy", International Finance, 2(1), pp.63-83.

Barro, R. J., and D. B., Gordon, (1983), “A Positive Theory of Monetary Policy”, Journal of Political Economy, Vol. 91 (August), pp.589-610.

Batini, N., (2002), "Euro Area Inflation Persistence," European Central Bank, Working Paper Series, Vol. 4, No. 201.

, and Nelson E., (2001), "The Lag from Monetary Policy and Actions to Inflation: Freidman Revisited”, International Finance, Vol. 4, No.3, pp.381-400.

Bernanke, B.S., and Blinder A.S., (1992), "The Federal Funds Rate and the Channels of Monetary Transmission”, American Economic Review, Vol. 82, No.4, pp.901-921.

, and I. Mihov, (1998), "Measuring Monetary Policy", Quarterly Journal of Economics, Vol. 113, No.3, pp.869-902.

Brayton, F., Andrew L., Ralph T. and Williams, J. C., (1997), “The Evolution of Macro Models at the Federal Reserve Board", Carnegie-Rochester Conference Series on Public Policy, Vol. 47, pp.43-81. 
Burdekin, R.C.K., and Siklos, P. L., (1999), "Exchange Rate Regimes and Shifts in Inflation Persistence: Does Nothing Else Matter", Journal of Money, Credit and Banking, Vol. 31 (May), pp.235-47.

Calvo, G. A., (1983), "Staggered Prices in a Utility Maximizing Framework", Journal of Monetary Economics, Vol. 12(3) (September), pp.983-98.

, and Reinhart C. M., (2002), "Fear of Floating”, Quarterly Journal of Economics, Vol. 117 (May), pp.379-408.

Central Bank of Sri Lanka, Annual Reports, (2001) and (2005).

Chadah B., Masson, P. R. and Meredith D., (1992), "Models of Inflation and Costs of Disinflation”, IMF Staff Papers, Vol. 39, pp.395-431.

Christiano, L. J., Eichenbaum M., and Evans C. L., (1999), "Monetary Policy Shocks: What we have Learned and to What End?", Handbook of Macroeconomics, Vol. 1A, pp.65-148.

, (2001), "Nominal Rigidities and the Dynamic Effects of a Shock to Monetary Policy", NBER Working Paper, No. 8403.

Clarida R., Gali, J. and Gertler, M., (1999), "The Science of Monetary Policy, A New Keynesian Perspective”, Journal of Economic Perspectives, Vol. 37(4), pp.1661-1707.

Clark, P., Laxton, D. and Rose, D. (1996), “Asymmetry in U.S. Output Inflation Nexus”, IMF Staff Papers, Vol. 43, pp.216-51.

Cogley T. and Sargent T.J., (2001), "Evolving Post World War II U.S. Inflation Dynamics”, NBER Macroeconomics Annual, mimeo.

Dornbusch, R, (1982), “PPP Exchange Rate Rules and Macroeconomic Stability”, Journal of Political Economy, Vol. 90, pp.158-65.

Enders W., (2003), Applied Econometric Time Series, 2nd edition, John Willy and Sons, Inc.

Friedman M., (1972), “Have Monetary Policies Failed?”, The American Economic Review, Vol. 62(1/2), pp.11-18.

Fuhrer, J, C., (1997), "The (Un)Importance of Forward Looking Behaviour in Price Specifications", Journal of Money, Credit and Banking, Vol. 29(3) August, pp.338-50.

, and Moore, G. R., (1995), “Inflation Persistence”, Quarterly Journal of Economics, Vol. 110, pp.127-60

Gali, J. and Gertler, M., (1999), "Inflation Dynamics: A Structural Econometric Analysis”,
Journal of Monetary Economics, Vol. 44(2) (October), pp.195-222.

, and Lopez-Salido, J. D., (2001), “European Inflation Dynamics”, European Economic Review, Vol. 45, pp.1237-70.

(2005), "Robustness of Estimates of the Hybrid New Keynesian Phillips Curve", Journal of Monetary Economics, Vol. 52, pp.1107-118.

Goldstein, M. and Khan, M.S., (1976), "Large Versus Small Price Changes in the Demand for Imports", IMF Staff Papers, Vol. 23, pp.200-225.

Gujarati, D. N., (1999), Essentials of Econometrics, 2nd Edition, The McGraw-Hill Companies, Inc.

Hamilton, J. D., (1994), Time Series Analysis, Princeton University Press, Princeton.

International Monetary Fund, (2005), "De Facto Classification of Exchange Rate Regimes and Monetary Policy Framework" as of July 31 2006, (http://www.imf.org/external/np/ $\mathrm{mfd} / \mathrm{er} / 2006 / \mathrm{eng} / 0706 . \mathrm{htm})$

Kara, A. and Nelson, E., (2002), "The Exchange Rate and the Inflation In UK”, Bank of England, Discussion Paper, No. 11.

Levy-Yeyati, E., and Sturzenegger, F., (2005), "Classifying Exchange Rate Regimes: Deeds Vs. Words”, European Economic Review, 49, 1603-1635.

Linde, J., (2005), “Estimating New Keynesian Phillips Curve: A Full Information maximum Likelihood Approach”, Journal of Monetary Economics, Vol. 52(6), pp.1135-149.

Mankiw, G. N., (2001), "The Inexorable and Mysterious Trade-off Between Inflation and Unemployment”, The Economic Journal, III (May), C45-C61.

McCallum, B T. (1997), “The Alleged Instability of Nominal Income Targeting”, NBER Working Paper, No. 6291.

,(1999), “Analysis of the Monetary Transmission mechanism: Methodology Issues”, NBER Working Paper, No. 7395.

, and Nelson, E., (1999), "Nominal Income Targeting in an open economy Optimizing Model," Journal of Monetary Economics, Vol. 43, pp.553-78.

McCandless, G. T. and Weber, W. E., (1995), "Some Monetary Facts", Federal Reserve Bank of Minneapolis Quarterly Review, Vol.19 (3), p.2-11.

Neiss K. and Nelson E., (2005), "Inflation Dynamics, Marginal Cost, and the Output Gap: Evidence from Three Countries", Journal of Money Credit and Banking, Vol. 37(6) pp.1020-45. 
Obstfeld, M, (1995), “International Currency Experience: New Lessons and Lessons Relearned", Brooking Papers on Economic Activity, pp.119-220.

Reinhart, C. M., and Rogoff, K. S., (2004), "The Modern History of Exchange Rate Arrangements: A Reinterpretation”, Quarterly Journal of Economics, 119, 1-48.

Roberts, J. M., (1995), "New Keynesian Economics and the Phillips Curve”, Journal of Money, Credit and Banking, Vol. 27, pp.975-84.

, (1997), "Is Inflation Sticky?", Journal of Monetary Economics, Vol. 39 (September), pp.173-96.

\section{Unpublished.}

(1998), "Inflation Expectations and the Transmission of Monetary Policy",

Rogoff, K., (1985), "The Optimal Degree of Commitment to an Intermediate Monetary Target: Inflation Gains versus Stabilization Costs", Quarterly Journal of Economics, Vol. 100 (November), pp.1169-89.

Rogoff, K. and Carmen M. R., (2002), "The Modern History of Exchange Rate Arrangements: A Reinterpretation", NBER Working Papers, No. 8963.

Rudd, J. and Whelan, K., (2005), "Modelling Inflation Dynamics: A Critical Survey of Recent Research", Paper prepared for FRB/ JMCB Conference.

Rudebusch, G. D., (2002), “Assessing Nominal Income Rules for Monetary Policy with Model and Data Uncertainty”, The Economic Journal, Vol. 112(479), pp.402-32.

Sbordone, A. M., (2001), "An Optimizing Model of U.S. Wage and Price Dynamics", Rutgers University.

, (2002), "Prices and Unit Labor Costs: A New Test of Price Stickiness", Journal of Monetary Economics, Vol. 49, pp.265-92.

Shambaugh, J. C., (2004), "The Effects of Fixed Exchange Rates on Monetary Policy", The Quarterly Journal of Economics, 301-352.

Sheedy, K. D., (2005), "Structural Inflation Persistence", University of Cambridge, mimeo.

Svensson, L., (1994), "Fixed Exchange Rate as a Means to Price Stability: What Have We Learned?", European Economic Review, Vol. 38, pp.447-68.

, (1997), "Optimal Inflation Contracts, 'Conservative' Central Banks, and a Linear Inflation Contracts”, American Economic Review, Vol. 81(1) Mar, pp.98-114.
Taylor, J. B., (1979), "Staggered Wage Setting in a Macro Model”, American Economic Review, papers and proceedings, 69, pp.108-13.

(1980), "Aggregate Dynamics and Staggered Contracts", Journal of Political Economy, Vol. 88, pp.1-23

, (2000), "Low Inflation, Pass-through, and the Pricing Power of Firms", European Economic Review, Vol. 44, pp.1389-408.

,(2000), "The Monetary Transmission Mechanism and the Evaluation of Monetary Policy Rules”, Central Bank of Chile Working Papers, No.87.

Thenuwara H. N. , (1998), "Inflation Targeting in Sri Lanka: A Focus on the Transmission Mechanism”, Staff Studies, Central Bank of Sri Lanka, Vol. 27-28, pp.15-37.

Walsh C. E., (2003), Monetary Theory and Policy, 2nd edition, MIT Press.

White, H., (1980), "A Hetroscedasticity-Consistent Covariance Matrix and a Direct Test for Hetroscedasticity", Econometrica, Vol. 48, pp.817-38.

Woodford, M., (2001), "Inflation Stabilization and Welfare", NBER Working Paper, No.8071.

(2003), Interest and Prices: Foundations of a Theory of Monetary Policy, Princeton University Press, Princeton. 


\section{Appendix A}

\section{Data Description}

The main data source is the IMF's International Financial Statistics (IFS) database for the period 1960Q1 to 2005Q4. The incomplete IFS data series are updated using data from the Annual Reports of the Central Bank of Sri Lanka (CBSL) and internal sources. All data series are seasonally adjusted, before logged, using Census X-12, in order to normalise seasonal fluctuations.

(a) cpi - The log of Consumer Price Index for Sri Lanka (1952=100). The percentage weights are based on the average expenditure of a sample of working class households as per the Colombo Family Budget Survey in 1949/50 revalued at prices in 1952 .

- The log of oil price based on the Dubai Spot Price Index obtained from IFS. To account for the effects of nominal exchange rate fluctuations the following adjustment is made: $\Delta o i l_{t}=\left(f_{t}-f_{t-1}\right)+\left(s_{t}-s_{t-1}\right)$, where $f_{t}$ and $s_{t}$ refer to log of oil price index values and the nominal exchange rate, respectively.

(c) imp - The log of (Real) import price based on the Import Price Annual Index $(1990=100)$ taken from the Annual Report 2003 (Table 17) of the Central Bank of Sri Lanka. The quarterly series is obtained by quadratic interpolation using Goldstein and Khan method (1976). The real import price inflation is obtained by adjusting for domestic consumer price inflation: $\Delta i m p_{t}=\left(m_{t}-m_{t-1}\right)-\left(p_{t}-p_{t-1}\right)$, where $m_{t}$ and $p_{t}$ refer to log of import price index values and consumer price index, respectively.

(d) gdp - The log of gross domestic price series at constant prices: A quarterly GDP data series is not available for the entire sample period. The existing data series in the CBSL starts from 1996Q1. Therefore, a quarterly real GDP data series is generated through quadratic interpolation using Goldstein and Khan method. The interpolated series is replaced by the existing series (seasonally adjusted) since 1996Q1.

(e) gap - The quarterly output gap measure is computed as the difference between $\log$ of real GDP (seasonally adjusted) series and the long-term trend output series obtained from the Hodrick-Prescott (HP) filter. The smoothing parameter 1600 is used as data series is in quarterly basis.

(f) exrate - The log of quarterly nominal exchange rate series, based on the market rate as per the amount of domestic currency units per US dollar. (g) reer - The log of real (effective) exchange rate series, calculated using consumer price indices and relative trade shares for four major trading partners with Sri Lanka, namely India, Japan, the United Kingdom and the United States. These countries represent a major share of the volume of international trade in Sri Lanka during the sample period. For each country the bilateral real exchange rate is computed according to the formula,

$$
R E R=E_{i j} \frac{P_{j}^{*}}{P_{i}}
$$

where, $E$.is the nominal exchange rate between Sri Lanka and $j^{\text {th }}$ country, expressed as domestic currency units per foreign currency and taken as quarterly averages (spot rates) in order to be compatible with the quarterlyaverage price levels. $P_{j}^{*}$ and $P_{i}$ refer to consumer price indices of foreign country and the domestic price level, respectively. All bilateral real exchange rates are transformed in to an index based on 2000, as the price indices are also in the same base year. The trade weights are computed based on the average of total exports and imports with each trading partner. Finally, the real effective exchange rate is obtained by assigning the trade weights to the real exchange rate on quarterly basis. Accordingly, a rise in real effective exchange rate indicates a depreciation of domestic currency and vice versa.

(h) ir _ - The nominal interest rate series which represents the Treasury Bill rate is obtained from IFS for the period starting from 1981Q1. The Advance Rate (Bank Rate) is used for the earlier period.

(i) reir - The real interest rate is obtained by taking the difference between the nominal interest rate series and consumer price inflation series.

(j) $\mathbf{M}_{1} \quad-\quad$ The log of narrow money supply

(k) $\mathbf{M}_{2} \quad$ - The log of money plus quasi money

(l) rmoney- The log of reserve money (the monetary base) 